NBER WORKING PAPER SERIES

\title{
DEFINED BENEFIT PENSION PLAN DISTRIBUTION DECISIONS BY PUBLIC SECTOR EMPLOYEES
}

\author{
Robert L. Clark \\ Melinda S. Morrill \\ David Vanderweide \\ Working Paper 18488 \\ http://www.nber.org/papers/w18488
}

\author{
NATIONAL BUREAU OF ECONOMIC RESEARCH \\ 1050 Massachusetts Avenue \\ Cambridge, MA 02138 \\ October 2012
}

This research was supported in part by a grant from the U.S. Social Security Administration (SSA) funded as part of the Financial Literacy Research Consortium. An earlier version of the paper was presented at the "Retirement Benefits for State and Local Employees: Designing Pension Plans for the Twenty-First Century" conference, which was funded by the Smith Richardson Foundation. The opinions and conclusions expressed herein are solely those of the authors and do not represent the opinions or policy of SSA, any agency of the Federal Government, the National Bureau of Economic Research, or any other institution with which the authors are affiliated. The authors would like to thank Olivia S. Mitchell, Thayer Morrill, and James Poterba for helpful comments.

At least one co-author has disclosed a financial relationship of potential relevance for this research. Further information is available online at http://www.nber.org/papers/w18488.ack

NBER working papers are circulated for discussion and comment purposes. They have not been peerreviewed or been subject to the review by the NBER Board of Directors that accompanies official NBER publications.

(C) 2012 by Robert L. Clark, Melinda S. Morrill, and David Vanderweide. All rights reserved. Short sections of text, not to exceed two paragraphs, may be quoted without explicit permission provided that full credit, including (C) notice, is given to the source. 
Defined Benefit Pension Plan Distribution Decisions by Public Sector Employees

Robert L. Clark, Melinda S. Morrill, and David Vanderweide

NBER Working Paper No. 18488

October 2012

JEL No. H75,J45

\begin{abstract}
Studies examining pension distribution choices have found that the tendency of private-sector workers is to select lump sum distributions instead of life annuities. In the public sector, defined benefit pensions usually offer lump sum distributions equal to employee contributions, not the present value of the annuity. Using administrative data from the North Carolina state and local government retirement systems, we find that over two-thirds of public sector workers under age 50 separating prior to retirement from public plans in North Carolina left their accounts open and did not request a cash distribution from the pension system within one year of separation. Furthermore, the evidence suggests many separating workers, particularly those with short tenure, may be forgoing important benefits due to lack of knowledge, understanding, or accessibility of benefits. In contrast to prior research in the private sector, we find no evidence of a bias toward cash distributions for public employees in North Carolina.
\end{abstract}

Robert L. Clark

Poole College of Management

Box 7229

North Carolina State University

Raleigh, NC 27695

and NBER

robert_clark@ncsu.edu

Melinda S. Morrill

Department of Economics

North Carolina State University

Box 8110

Raleigh, NC 27695-8110

melinda_morrill@ncsu.edu
David Vanderweide

Fiscal Analyst

Fiscal Research Division

North Carolina General Assembly

Raleigh, NC 27601

david.vanderweide@ncleg.net 


\section{Introduction}

Each year, millions of American workers leave their jobs either by choice or due to termination by their employers. Many of these job changers participate in defined benefit pension plans. On leaving their employers, these workers are often given a choice of keeping their retirement accounts open, thus maintaining a claim on a future life annuity, or accepting an immediate lump sum distribution (LS) of their pension assets. Workers who accept the LS are then given a choice of whether they want to roll the funds over into an IRA or to accept the cash as taxable income and also pay a tax penalty for early withdrawal if under age 59.5. These choices can have significant long run implications for future retirement income.

Economic theory argues that to maximize lifetime utility one should consume such that utility levels are smooth over time. One method of achieving utility smoothing is through the purchase of annuities (Yaari, 1965). However, a series of national surveys and economic studies have found that individuals rarely purchase annuities in the open market (see, e.g., Mitchell, et al., 1999). Further, when given the choice in their pension plans of a life annuity or a LS, workers often choose the LS (see, e.g., Brown, 2001; Engelhardt, 2002; Hurd and Panis, 2006). Thus, workers tend to reject the opportunity to receive a certain flow of income throughout retirement in favor of receiving cash now, which therefore results in individuals assuming the task of managing funds on their own during their retirement years. This conflict between theory and individual choices has been called the "Annuity Puzzle.",

Under federal pension regulations, defined benefit plans in the private sector must offer an annuity and provide participants with information on their future annuities. The LS's for these

\footnotetext{
${ }^{1}$ See Benartzi, et al., (2011) for an excellent overview of the 'annuity puzzle' literature.
} 
plans are required to be calculated as at least equal to the present value of the retirement annuity using approved interest and mortality tables. ${ }^{2}$ Things are very different in the public sector. Public sector defined benefits plans usually require explicit employee contributions each pay period, and LS's are based on the employee contributions and not the present value of the annuity. Thus, a public sector worker's choice of whether to take a LS reflects both his/her individual preference for annuitization and potential differences in the net value of the LS and annuity options. Defined benefit plans continue to cover most state and local employees and virtually all of the plans offer workers the option of a LS at job separation or retirement (Clark, Craig, and Sabelhaus, 2011).

We examine the choices terminated workers make using data from the North Carolina Teachers' and State Employees' Retirement System (TSERS) and the North Carolina Local Governmental Employees' Retirement System (LGERS) using information contained in the administrative records of the two retirement plans. ${ }^{3}$ As of the end of 2010, these two public pension plans covered 803,636 employees and retired workers. Our unique dataset contains all terminations from state and local government employment in North Carolina between 2007 and 2008 and tracks behavior through the end of 2009, allowing us to observe choices made within one year of separation for all terminated workers. The dataset includes relevant economic and

\footnotetext{
${ }^{2}$ The Pension Protection Act requires that beginning in 2008 the LS be calculated using a three-segment interest rate yield curve based on the rates of return on investment grade corporate bonds of varying maturities. Purcell (2007) provides additional information on this process and how it affects workers at various ages at termination.

${ }^{3}$ While these plans have separate governing boards, they are administered by the same staff and have similar, but not identical, benefits and contributions requirements. Further details of TSERS and LGERS can be found by visiting the retirement systems' home page at:

http://www.nctreasurer.com/dsthome/RetirementSystems.
} 
demographic information on all individuals who left state or local employment during this time period.

Public sector defined benefit plan participants face a series of choices concerning their pension accounts when terminating employment prior to retirement, as illustrated in Figure 1. The first decision a worker must make is whether to maintain his/her pension account or accept an immediate LS. ${ }^{4}$ From an economic perspective, a worker should compare the value of the LS to the present discounted value of the life annuity (PDVA) which is set to begin at some point in the future. However, as we will see later, there are a number of factors that make this decision more complicated that a simple wealth comparison.

[Figure 1]

The default option is for the worker to maintain the pension account; a departing worker must file a request with the retirement system in order to receive a LS. Depending on the rules of the pension plan, a worker might also have the opportunity to return to work with the same employer and have prior service credits count toward a future retirement benefit. ${ }^{5}$ Figure 1 also shows that workers who request a LS must specify whether they want to receive cash or have the funds rolled over into another approved tax qualified retirement plan such as an IRA. If the worker is sent a check, she could subsequently deposit the funds into an IRA and avoid current taxes and penalties if she follows the IRS guidelines. It is important to remember that

\footnotetext{
${ }^{4}$ The term "maintain" is used because workers may have the opportunity to request a LS at any time after separating from public employment and prior to starting a retirement benefit; thus not accepting the immediate LS leaves open the option of requesting such a distribution at some time in the future instead of waiting until one is eligible to start a retirement annuity from the plan. In our analysis, "immediate" means that the terminated worker requested a LS within one year of termination.

${ }^{5}$ Returning to work and being covered by the same retirement plan is probably much more likely in the public sector where a single plan typically covers all state employees and teachers in the state. This allows workers to change jobs and government agencies and to move within the state while remaining in the same retirement system.
} 
individuals preferring to insure against longevity risk by annuitizing have the option to withdraw funds, roll them over into an IRA, and ultimately purchase an annuity. Thus, an informed worker should decide whether to withdraw funds based on the highest present value of the distribution options, appropriately measured, taking into account predicted inflation, interest rates, and various types of risk.

We calculate how the decisions made by separating workers are affected by the value of the distributional options available to them. The relative generosity of the two options is estimated using details of the plan characteristics and information provided by the retirement system. Surprisingly, we find that fewer than one-third of all terminating public employees requested a LS within one year of separation, despite the finding that for over 70 percent of terminations, the LS was larger than the estimated PDVA.

We offer several potential explanations for why the distributional choice from a public pension plan is more complex than a simple wealth comparison at a point in time. First, separating participants in TSERS qualify for retiree health insurance from the State Health Plan with no premium as long as they are receiving a monthly annuity from TSERS. This option is available for virtually all vested state employees (participants in TSERS), but local employees (participants in LGERS) are not covered by the State Health Plan. ${ }^{6}$ Comparing distributional decisions by state employees in TSERS to those of local employees in LGERS provides some indication of the effect of retiree health insurance on the choice to ultimately receive a retirement annuity. Despite the difference in coverage of retiree health insurance in the two systems, we do

\footnotetext{
${ }^{6}$ With a few minor exceptions, workers and retirees covered by LGERS are not covered by the State Health Plan; however, they may be covered by locally-managed health plans that extend coverage to retirees. We cannot match the local health plans to the LGERS retirement data.
} 
not see a large difference in the distributional choices between separating workers that will qualify for retiree health insurance and those that will not.

Second, we consider the likelihood that terminated participants may plan to return to public employment. The expectation of returning to public employment might make maintaining the account the optimal choice for these individuals. However, we document that workers who ultimately returned to work by December 2010 were actually more likely to withdraw funds within one year of separation. Next, we highlight that maintaining the account still allows for the option of requesting a LS at some future date. Because the account balance accrues interest at a guaranteed rate of 4 percent, financially savvy individuals may choose to maintain their account balances and accept larger LS's at a future date as part of an investment portfolio. Still, we do not see a large difference between the disposition choice of non-vested workers (who do not earn interest) and vested workers. Finally, we address the role that confidence in the retirement system, financial literacy, and inertia may play in the choice to accept a LS. The default is to leave funds in the system. The behavior we observe is consistent with many individuals accepting the default option and forgoing potentially more valuable benefits.

After the analysis of the decision to accept a LS rather than maintaining one's account balance, we then examine the decision between cash and a rollover of pension assets by those who opted for a LS. The decision on spending versus saving the LS distribution has received considerable attention by economists; however, only a few studies have been able to observe this choice in administrative records rather than survey data (see Bryant, Holden, and Sabelhaus, 2011). We find that nearly 90 percent of separating workers that request a LS elect to receive the funds as cash, rather than rolling over. Of course, individuals who select a cash distribution can 
still move the funds into a retirement account, pay off debts, or save in non-retirement accounts, rather than spending the money on immediate consumption.

This study finds that separating workers tend to leave their pension accounts open instead of requesting cash distributions of their pension wealth when leaving these public pension systems. Thus, among these public employees, there is no obvious annuity puzzle as most workers retain their option of receiving a life annuity even when the LS is greater than the PDVA. We do not observe a sharp change in the proportion of separating workers taking a lump sum distribution by vesting status, nor are workers with a higher present discounted value of their future annuity substantially less likely to withdraw funds.

\section{Previous Literature Examining Lump Sum Distributions}

Economists have long been interested in how workers access and utilize the wealth accumulated in their retirement accounts. For the most part, research studies have focused on (1) the choice between a lump sum distribution (LS) and an annuity at retirement, and (2) the decision by terminating workers who take a LS to accept a cash distribution or roll over the funds over into another tax qualified retirement plan. Papers on the first topic are often linked to the 'annuity puzzle' and try to explain why economic theory suggests individuals would prefer an annuity but retiring workers largely prefer LS's. Most studies on the second point use survey data which relies on individuals' ability to recall whether they spent or saved the LS. There are only a few papers that consider the choice at termination between a LS and maintaining the account balance; rarely have any studies explicitly examine terminations from public retirement 
plans. $^{7}$ A notable exception is Warner and Pleeter (2001), who estimate decisions in a military pension plan. ${ }^{8}$

Most studies that have examined the choice of a LS have focused on respondents in large national data sets (e.g., SIPP, HRS). For the most part, these studies have not recognized the difference between public and private workers leaving employment. Economic theory indicates that workers will compare the cost of purchasing an annuity that is based on population agespecific mortality rates to the present value of the annuity using their personal discount rates and their own life expectancies. Workers who believe that an annuity based on population life expectancy will be less than actuarially fair to them should accept the LS (Hurd and Panis, 2006). Individuals with high personal discount rates will place a lower value on the future annuity and thus be more likely to accept the LS.

Earlier studies have found that when the value of the cash settlement is relatively small, there is a greater likelihood that workers will take the LS and not roll these funds over into another retirement account, thus rejecting a future life annuity (Hurd and Panis, 2006; Poterba et al., 1998, 2001; Sabelhaus and Weiner, 1999; Engelhardt, 2002). Hurd and Panis (2006) observe that women are more likely to request cash settlements than men, as are workers with less formal education. However, others find that men are more likely to take LS's (Butler and Teppa, 2007;

\footnotetext{
${ }^{7}$ An expanded model of pension decisions by individuals would include the initial choice of whether to select a DB plan or a DC plan as their primary retirement plan. This choice is a function of investment risk, labor market risk, and a variety of other factors including whether the worker prefers their retirement plan to provide a retirement annuity or a LS. In the past decade, a number of states have given newly hired employees this option (Clark, Craig, and Sabelhaus, 2011). Several recent papers have examined the choice of pension plans in the public sector (e.g., Brown and Weisbenner 2012; Papke 2004; Yang 2005)

${ }^{8}$ Other papers that examine distributional choices from public plans include Chalmers and Reuter (2009) and Butler and Teppa (2007); however, these papers examine the distributional choice at retirement. See Benartzi, Previtero, and Thaler (2011) for a discussion of distributions at retirement in the private sector.
} 
Purcell, 2009). Older workers are found to be more likely to roll over their pension distributions (Burman, Coe, and Gale, 1999; Moore and Muller, 2002; Warner and Pleeter, 2001). Many of these previous studies address workers' implied discount rates and the effect of high discount rates that minimize the value of the future annuity compared to the LS. ${ }^{9}$ The choice between money now and a lifetime annuity beginning years in the future is also influence by financial literacy. Considerable recent evidence indicates that American workers have a relatively low level of financial literacy (Lusardi and Mitchell, 2007). Workers that lack a good understanding of financial mathematics, financial market risks, and the uncertainty associated with mortality might not be able to determine the optimal choice when faced with important financial decisions such as the choice of a LS versus a future annuity (see, e.g., Clark, Morrill, and Allen, 2012).

Despite the impressive list of studies that have examined distributional choices and the use of LS's, there remain several important shortcomings in these analyses. First, relatively few studies have examined the choices made by public sector employees. This is an important gap because the distributional options in public sector plans quite different than those in the private sector, and defined benefit plans are much more prevalent in the public sector. Second, most prior studies used survey data and hence relied on respondents' recall of decisions made years earlier. The reliance on memory of these events undoubtedly introduces considerable noise. In contrast, our analysis focuses on separations from a public defined benefit plan using administrative records showing real-time decisions.

\footnotetext{
${ }^{9}$ Other papers that examine the utilization of a LS include Bassett, Fleming, and Rodriguez (1998), Chang (1996), Copeland (2009), and Yakoboski (1997).
} 


\section{Estimating the Value of Distribution Options in the North Carolina Retirement}

\section{Plans}

\subsection{Background on Distributional Choices in State-Managed Defined Benefit Plans}

In public sector defined benefit plans, the default option for departing workers who are vested is to leave their funds in the pension plan and receive an annuity when they have attained the required age for starting benefits. ${ }^{10}$ All public defined benefit plans that we have examined offer departing workers the option of leaving their funds in the pension system, thus retaining their eligibility to receive a retirement annuity when they reach the specified age and service requirements of the plan. ${ }^{11}$ Most public plans allow separated workers to request a lump sum distribution (LS) at any point up until the individual starts the retirement annuity.

Private sector defined benefit plans usually do not entail employee contributions. ${ }^{12}$ In public retirement plans, on the other hand, employee contributions are typically required. ${ }^{13}$ All state retirement plans that require employee contributions for all plan participants offer a LS

\footnotetext{
${ }^{10}$ Ultimately, the default is that no benefits are paid. Terminated workers who do not request a lump sum distribution are defaulted into keeping their account open. When workers finally satisfy age and service requirements for a benefit, they still must request that their retirement benefits be paid. No request from the terminated worker means that no benefit is paid. Data from the North Carolina retirement system show that only in a relatively small number of cases did workers leave public employment and never request either a LS or the start of an annuity.

${ }^{11}$ Workers who had not yet been employed sufficient years to achieve vesting would have to return to a public job covered by the same pension and work additional years to satisfy the vesting requirements before they would be eligible to receive a future pension benefit.

12 The Bureau of Labor Statistics (2011) reports that only 4 percent of workers that are participating in defined benefit plans in the private sector are enrolled in plans that require an employee contribution. ${ }^{13}$ According to Clark and Hanson (2011), only a few state retirement plans do not require workers to contribute a portion of their salary in support of the retirement plan. These plans include Arkansas PERS, Connecticut SERS, Florida FRS, Hawaii ERS, Michigan PSERS and SERS, Missouri MSEP, Tennessee CRS, and Utah SRS. In these noncontributory plans, non-vested terminated workers are not eligible to receive a future retirement annuity, nor are they eligible for a LS. The Bureau of Labor Statistics (2011) reports that 79 percent of state and local workers that are participating in defined plans are enrolled in plans that require employee contributions with the mean contribution rate being 6.5 percent of earnings.
} 
option to terminated employees. Separating workers in these plans are offered a LS at least equal to their own contributions. In some states, individuals are also awarded interest payments on their contributions. The interest rate varies across states and is often a function of years of service. The average interest rate paid on employee contributions among those states with interest payments is 4 percent per year with a standard deviation of 2 percent (Clark and Hanson, 2011). While the empirical analysis of the distributional choices reported in this paper uses administrative records only of North Carolina retirement plans, the choices and plan parameters imbedded in the North Carolina system are similar to those in other retirement plans covering teachers and state employees. ${ }^{14}$

\subsection{Choices Facing Separating Public Sector Workers in North Carolina}

Employees who leave public employment in North Carolina must decide whether they will accept a LS or leave their pension account open in anticipation of a retirement annuity payable from the required age for retirement benefits. The LS can be known with certainty; however, the present value of the annuity involves a more difficult calculation which should reflect personal discount rates, expected inflation rates, and the likelihood of returning to public employment in North Carolina. In order to understand the choice between accepting a LS and leaving pension assets in the system, one must consider key parameters of the pension plan and how they affect the value of the LS that is available at separation versus the annuity expected in the future. Public sector workers in North Carolina are also covered by Social Security and Medicare.

\footnotetext{
${ }^{14}$ Clark and Hanson (2011) provide a detailed summary of the distribution choices available to teachers and state employees in all 50 states.
} 
Like most public retirement plans, both retirement systems in North Carolina (TSERS and LGERS) require employee contributions. The required employee contributions are equal to six percent of total annual salary and are deducted from paychecks every pay period. These contributions are deposited in the retirement funds of the two state systems and help finance the benefits for retirees. In both North Carolina systems, vesting occurs when an employee completes five years of service. ${ }^{15}$ If workers leave public employment prior to being vested, their LS is simply the total of their own contributions to the system; in other words, non-vested separating workers do not receive any interest credited on these contributions and they do not receive any portion of the employer pension contributions. Workers leaving public employment with at least five years of service are offered a LS equal to the total of their own contributions during their employment plus interest credited at four percent per year. As is typical of most state defined benefit plans, even once vested North Carolina public employees who request a LS have no claim on the implied employer contributions to the retirement plan.

The value of the LS is equal to the total employee contributions (plus interested if vested) and can be calculated directly from the salary history. Appendix A describes the calculation, which is a direct function of starting salary, wage growth, years of service, and the interest rate, but is independent of sex or age. Departing employees can learn the value of their LS by checking their account balances on-line or by directly contacting the retirement system. Thus, the value of one's LS can be known with certainty at the time of separation.

\footnotetext{
${ }^{\mathbf{1 5}}$ Legislation in 2011 raised the vesting requirement from five years of service to ten years for all newly hired teachers and state employees; however, in the sample we consider, all workers are covered by the five year vesting provision.
} 
The retirement benefit is calculated in a similar fashion to that typically found in the private sector, using a benefit formula based on years of service and final average salary. The systems do not provide an estimate of the present discounted value of the annuity (PDVA) to its members. Using the estimated benefit for each departing worker, we derive the present value of a future annuity for vested workers in the North Carolina TSERS or LGERS retirement system using the same assumptions employed by the retirement plans to calculate their pension liabilities. Details of this calculation are provided in Appendix A. The PDVA is calculated assuming that the individual will begin receiving an unreduced benefit at age $65{ }^{16}$

To reiterate, the PDVA is not used by the plan to calculate the LS and this value is never provided to terminated workers. Instead, the PDVA variable represents our estimate using the same life tables used by plan actuaries to evaluate the financial status of the plan, along with real and nominal interest rates, described in Appendix A. Workers with higher personal discount rates will place a smaller value on the annuity, as will those that believe that they have lower life expectancies. The value of the annuity is increasing in salary level and the rate of salary growth, as well as number of years of service, similar to the LS. However, the PDVA is also an increasing function of age at separation. In addition, because women's survival probabilities are

\footnotetext{
${ }^{16}$ Workers with 30 years of service can receive an unreduced benefit at any age; however, in the sample of separated employees that we examine, there are no individuals with 30 years of service. In addition, early retirement benefits are available to employees with 20 years of service at age 50; however, there are substantial reductions for accepting early retirement benefits. The magnitude of the reduction in annual benefits for starting benefits prior to reaching the normal retirement age vary with age and years of service. The benefit reductions for TSERS are presented in the employee handbook page 8, http://www.nctreasurer.com/NR/rdonlyres/223AE566-7BA0-471F-B02C0A18ABDB97C0/0/NC_TeaState_070111_Final.pdf. System records indicate that only about 25 percent of terminated vested workers wait until age 65 to start benefits; however, the reduction factors imposed by the system for early retirement mean that this assumption does not substantially alter the expected present value of the annuity. In other words, the reduction factors are, on average, approximately actuarially fair.
} 
higher than men's, women's PDVA will be (slightly) higher than men's with the same annual retirement benefit. ${ }^{17}$

A potentially important component of the retirement benefits for public workers in North Carolina is that the state will continue to provide health insurance for retirees in the TSERS system at no premium, provided that they are receiving a retirement annuity. ${ }^{18}$ Benefits are also available for the spouses and dependents of retirees, with only an implicit subsidy. ${ }^{19}$ For retirees over age 65, Medicare is the primary insurer and the state health plan (SHP) becomes the secondary insurer. For eligible state employees and teachers, the value of health insurance should be included in the worker's decision whether to request a lump sum distribution. However, as discussed further below, it is difficult to know how much an individual worker values access to state-provided retiree health insurance. We describe our calculation of the present value of the health insurance option in Appendix A.

The literature on the "annuity puzzle" highlights a potentially important role for health shocks (see, e.g., Brown, 2001). Individuals worried about unanticipated health care expenses may choose to keep assets liquid in order to have funds accessible in the event of a health shock. If a retiree does not have access to employer-provided health insurance, she may worry about the

\footnotetext{
${ }^{17}$ One could instead consider the size and terms of an annuity which could be purchased at the time of separation with the funds that are withdrawn. In the private annuity market, insurance companies will use similar interest rates to those we use in our calculations, but may also charge some commission and may adjust for adverse selection (see, e.g., Mitchell, et al., 1999). Because individuals could chose a variety of annuity products, we think framing the discussion in present value dollars using the assumptions adopted by the plan actuaries is a more straightforward comparison.

${ }^{18}$ All states have some form of retiree health insurance for their employees; however, the value of these plans differs markedly across the states, see Clark and Morrill (2010).

${ }^{19}$ In North Carolina, spouses and dependents must pay the full price of the premium, as calculated based on prior years' expenditures, so we do not consider the value of spousal or dependent benefits. There is an implicit subsidy due to risk pooling. Accounting for this would obviously increase the estimated value of the health insurance option.
} 
cost of health insurance coverage should an adverse health event occur. Retiree health insurance insures against this type of risk, and thus may be even more valuable to workers than the actuarially equivalent value.

\subsection{Simulating the Relative Values of the Annuity and Lump Sum Distribution}

As the above discussion indicates, the value of the LS depends on years of service but not on age at hire, while the PDVA is higher for those who are closer to the minimum required age of eligibility for retirement benefits. Thus, as employees accumulate years of service, the present value of the annuity will grow relative to the lump sum. The top portion of Figure 2 illustrates this trend using a hypothetical male worker in the TSERS retirement system with a starting salary of $\$ 30,000$ who experiences three percent wage growth per year. The values of the LS and PDVA are calculated for various ages of hire for a person with 10 years of service. The age where the two lines cross indicates the youngest age of hire at which the present value of the annuity exceeds the lump sum amount for a person with 10 years of service. The simulations indicate that for a separating employee with 10 years of service, workers hired at age 35 or older (thus age 45 or older at separation) have higher PDVA while workers hired before age 35 have higher LS values.

[Figure 2]

The bottom portion of Figure 2 illustrates a similar pattern, this time varying the years of service. For a worker hired at age 30 with a starting salary of $\$ 30,000$ and wage growth of 3 percent, the LS value will exceed the PDVA until about 15 years of service, at which point the PDVA becomes relatively more valuable. Figure 2 illustrates how age at hire and years of service affect the relative values of the LS and the PDVA; separating employees with fewer 
years of service or who are younger when hired are more likely to be facing LS values that exceed the PDVA values.

To get a more complete picture of how the various combinations of age at hire and years of service yield relative values of the two distribution options, we calculated the LS and PDVA amounts for a hypothetical worker with starting salary of $\$ 30,000$ per year and annual wage growth of 3 percent. Table 1 reports these simulated values for workers hired at various ages as their years of service increase from 5 to 25 years. The shaded boxes indicate the distributional option with the larger value for the indicated age/service combinations. One should note the years of service that must be completed before the PDVA overtakes the LS amount and how this crossing point varies by age of hire. For workers hired at age 25, the crossover point does not occur until after 20 years of service. At the other extreme, a worker hired at age 40 should anticipate an annuity with a present discounted value that exceeds the LS by five years of service, when vesting begins.

\section{[Table 1]}

These simple comparisons illustrate why it would not be surprising if a substantial proportion of terminated employees select the lump sum option. The LS will be greater than the present value of the annuity for many departing workers. This is in stark contrast to private sector defined benefit plans which are required by law to price the LS to be at least equal to the present discounted value of the annuity. These relative values suggest that one should observe a considerable proportion of vested workers requesting a LS at termination.

It is important to recognize that if one were to add the estimated present value of health insurance (calculation described in Appendix A) to the discounted value of the annuity for participants in TSERS, the value of the (cash plus health insurance) annuity is larger than the LS 
for vested terminated workers throughout their career. Thus, for vested workers who are eligible for retiree health insurance when they start receiving their retirement annuity, the simple present value calculation would suggest that virtually all of these terminated employees should maintain their funds with the state retirement plan. The value of retiree health is not very sensitive to age at separation due to the assumption that medical care costs are increasing at about the same rate as inflation, so the discounting effect on future health insurance is relatively small. For this calculation we assumed that workers retire at age 65 and do not claim retiree health insurance benefits until age 65, at which point they are eligible for Medicare as the primary insurer. If workers were to request an annuity and claim retiree health insurance earlier, the value of health insurance would obviously be larger, and we would predict even more individuals to choice the annuity option.

\section{Separating Public Employees in North Carolina: 2007 and 2008}

The state retirement system maintains records on current employees, terminated workers, and retirees consistent with the data needed to calculate and pay retirement benefits to plan participants. The data presented here are from the State of North Carolina's retirement systems (TSERS and LGERS) and contain information on all workers who left public employment during 2007 and 2008. The data include the employee's date of birth, sex, salary, and the retirement plan. In addition, the status of the account is included indicating whether the retiree is currently receiving retirement benefits (and when the benefits were initiated), whether and when 
she took a lump sum distribution (LS), or whether she left the funds in the plan and the account remained active (the retirement system refers to these as "dormant" accounts). ${ }^{20}$

Our sample includes workers who terminated employment in 2007 and 2008 and who did not retire and begin an annuity within one year of leaving the system. We restrict our attention to separating employees younger than 50 years old, in order to more closely approximate a sample that is not eligible to immediately begin a pension, even at a reduced level. Our sample includes 11,368 vested and 35,545 non-vested separating employees. Appendix B provides details on the data construction and how specific variables are defined, including vesting status and years of service.

To illustrate the distribution choices made by departing workers, Table 2 reports the number of vested and non-vested workers who left public employment in each year and the percent of each of the groups that accepted the LS within one year of separation. In the first column of Table 2, we see that about one-third of vested workers who left the retirement systems requested a LS within a year of termination. The second column of Table 2 reports a similar breakdown for non-vested workers. These are individuals who, based on service to date, will not be eligible for a retirement annuity and will not receive any interest on funds left with the system. While one might have predicted that nearly all non-vested terminated workers would select a LS, this is clearly not the case. Thus, it is important to attempt to explain why individuals made a choice that, on its face, seems to be financially costly. The patterns of

\footnotetext{
${ }^{20}$ In 2007, the state adopted a new reporting system, ORBIT, that records much more detailed information about the workers' separations. Data from earlier years do not provide sufficient information to analyze economic factors that influence the distributional choice.
} 
distributional decisions are reported separately for vested and non-vested workers for subgroups based on economic and demographic characteristics.

[Table 2]

Several similarities are observed in the behavior of vested and non-vested workers reported in Table 2. Interestingly, roughly one-third of both groups, vested and non-vested, accepted the LS within one year of termination. Women in both groups were significantly less likely to withdraw funds. Older workers in both groups were more likely to request a LS and those with more years of service in the non-vested group were also more likely to withdraw their pension funds, perhaps due to having a larger payment. All of the non-vested workers had relatively small account balances. For example, an individual that separated after three years of service whose annual salary was $\$ 30,000$ would have had approximately $\$ 5,500$ in his retirement account. Hence, there may be a threshold level that provides an incentive for workers to make a positive election for a LS, while those with only a few thousand dollars in their account may be less inclined to seek an immediate distribution. ${ }^{21}$ In contrast, among vested workers, those with the most years of service were the least likely to withdraw, which is not surprising given that the pension system is most generous for longer tenure workers. This is also consistent with findings that private sector workers tend to be less likely to request a LS the larger the account balance. Vested and non-vested participants in the LGERS were more likely to desire a cash distribution than those in the TSERS system. As described above, workers in TSERS are covered by the state health plan (SHP) and are eligible for free retiree health insurance, but only if they are currently receiving a retirement annuity from TSERS.

${ }^{21}$ See Benartzi, et al., 2011, for a discussion of threshold levels from behavioral economics. 
There are interesting differences in the desire for a LS across employment groups. The administrative records sort individuals by broad job classifications. Teachers and other educational professionals were much less likely to request a LS compared to other groups, with only about 20 percent having cashed out their pension accounts. On the other hand, skilled labor and public safety officers are among the most likely to have withdrawn.

For each of the individuals in our data, the exact value of the LS that they could have received at the time of separation is reported. For those that have non-missing salary and sex information, we use the assumptions described above to calculate an estimated present discounted value of the retirement annuity (PDVA) for vested participants. The value of the LS for each worker is then compared to our estimate of the PDVA. The bottom rows of Table 2 show that, of the 10,818 vested terminated workers for whom we can calculate the PDVA, the LS exceeds the PDVA for 7,977 individuals (73.7 percent of all vested terminations). ${ }^{22}$ Surprisingly, only about one third of separating workers in both groups (those where the LS exceeds the PDVA and those where the LS is less than the PDVA) requested a LS within one year of termination. This suggests that the relative value of the two distribution options did not strongly influence the choice made by separating employees. ${ }^{23}$

\footnotetext{
${ }^{22}$ Remember that this measure of PDVA includes only the value of the cash retirement benefit and does not include the estimated value of having access to the subsidized retiree health insurance. When this value is included, practically all vested workers have a higher PDVA compared to their account balance. ${ }^{23}$ Butler and Teppa (2007) describe a traditional measure of an annuity's value as its Money's Worth Ratio (MWR), which is the ratio of the present discounted value of the annuity payments and the initial cost. The MWR is then determined to be equal to one if the annuity is well-priced, with the difference usually attributed to adverse selection and administrative costs. In our formulation, the PDVA equal to the LS would be theoretically equivalent to a MWR of one.
} 


\section{Distributional Decisions of Vested Workers}

Next, we conduct a multivariate regression analysis of the choice to withdraw funds and accept a lump sum distribution (LS) within one year of separation for vested workers.

Theoretically, this assumes that the decision to leave is made and then the individual considers what to do with his retirement accounts. Access to a LS option and the size of account balance may influence a worker's decision to leave government employment; however, we do not model this relationship.

Earlier discussion has shown that we should anticipate differences in distributional choices based on certain personal and plan characteristics for two reasons. First, as the simulations reported in Section 3 demonstrate, the relative values of the distribution options are a function of a worker's age at hire, years of service, sex, and salary. Given differences in the two pension plans, one might also anticipate that distributional decisions will vary by participation in TSERS or LGERS. Second, previous research has shown that the choice to annuitize, holding constant the relative generosity of the distribution options, varies by sex, age, and the size of the pension account.

We seek to determine whether the choice to withdraw funds is due to underlying demographic characteristics affecting desire to annuitize, or to plan parameters affecting the relative generosity of the distribution options. We attempt to measure these two avenues by including both demographic controls (to the extent available in the data), as well as the size of the LS and our approximation of the present discounted value of the annuity (PDVA). Not only are some of the variables closely related, but the size of the LS and PDVA are both functions of salary and years of service, and age is an important determinant of the PDVA through its discounting effect (i.e., the same annual retirement benefit starting at age 65 has a higher present 
value for those age 45 compare to those age 35). The annual retirement benefit is exactly determined by annual salary and years of service, and the present value of this benefit is based on the assumed interest rate and age of the employee at termination. Thus, one should be concerned about the inclusion of age, years of service, salary, the value of the LS and the PDVA in the same specification, and we should expect that the estimated coefficients will be sensitive to the inclusion of all of these variables in the same specification.

With these caveats in mind, Table 3 presents coefficients estimated from a linear probability model of the decision to withdraw funds within one year of separation (request a LS) among workers who were vested in the retirement plan. ${ }^{24}$ We estimate the LS decision as a function of the value of the LS (the worker's account balance at separation), the calculated PDVA, and an indicator for whether the value of the LS exceeds the PDVA. We also include a separate intercept by year of termination to account for differences in economic conditions between 2007 and 2008. In columns (2) through (5), we incrementally add variables controlling for gender, state or local retirement plan (TSERS versus LGERS), a quadratic in final average salary, a quadratic in age at separation, a quadratic in years of service to observe how these variables affect the estimated coefficients on the values of the LS and PDVA.

[Table 3]

First, we observe that the value of the LS, which is equal to the employee contributions (6 percent of salary) plus interest, has a quadratic relationship whereby workers with larger values are less likely to request a LS until the account balances reaches approximately $\$ 73,000$.

Similarly, the estimate of the PDVA has a nonlinear effect on the distributional decision with

\footnotetext{
${ }^{24}$ The coefficients reported in Tables 3, 4, and 5 were estimated using linear probability models. Marginal effects from probit models are nearly identical and are available from the authors upon request.
} 
greater values increasing the likelihood of selecting a LS up to about $\$ 93,000$ and larger values reducing the probability of requesting a LS. The final variable in column (1) is an indicator variable for having an account balance (value of the LS) larger than the approximated PDVA. The estimated coefficient indicates that having a LS that is larger than the PDVA is associated with a 5.4 percentage point higher probability of requesting a LS. This is consistent with expectations, although, as discussed further below, the effect disappears when age at separation is added in Column (4). The estimates indicate that workers separating in 2008 were about 2 percentage points more likely to request a LS than those who terminated in 2007, and this difference becomes slightly larger once additional covariates are added to the model.

Columns (2) through (5) of Table 3 sequentially add covariates to the model. First, in Column (2), we see that men were 10 percentage points more likely to request the LS than were women who terminated employment. This is consistent with women being more likely to accept defaults. Terminated workers in TSERS were approximately 10 percentage points less likely to request a LS compared to comparable workers leaving LGERS, which is expected given the potential value of retiree health insurance for workers covered by TSERS. Introducing these two variables has virtually no effect on the estimated coefficients in the specification shown in Column (1).

In Column (3), we observe that the final average salary (i.e., the average salary over the past four full years of employment) has a u-shaped relationship with the probability of requesting a LS. The effect is negative up until a salary of over $\$ 112,500$ (depending on the specification) and then for higher salaries becomes positive. Adding the salary variable also has little effect on the other coefficients. Columns (4) and (5) report the estimates when age at separation and years of service are added to the model. Age has an inverted u-shaped relationship with distributional 
choice, where the youngest and oldest workers are least likely to choose a LS. Depending on the specification, the effect of age on the probability of receiving a LS is positive but declining up until the worker reaches approximately age 35 after which age has a negative effect on accepting a LS. One possible explanation for this pattern is that older workers are closer to being able to start a retirement annuity, so experience less discounting due to having to wait to claim the benefit. It may also reflect a greater confidence by older workers that retirement benefits will not be reduced for them or greater salience of the need for retirement income among workers nearer to retirement. Note that adding a quadratic polynomial in age to the regression reduces the estimated impact of having a larger value of the LS than the PDVA from being positive and significant to being negative and insignificant.

The relative size of the LS and PDVA is highly correlated with age, as illustrated in the simulations reported in Table 1 and shown in Figure 2. The annuity value is discounted back to the current age, so those who are closer to retirement have less discounting. Meanwhile, the LS is not a function of age, so older individuals are more likely to have higher PDVA than LS relative to younger individuals. We see this in the data where, for example, among workers age 45 and older at separation only 11 percent have larger LS's than PDVA's, while almost 90 percent of workers less than age 45 have a higher value of their LS than PDVA. It is therefore difficult to separately identify the effects of age and the relative value of the LS and PDVA.

In the final column of Table 3, we see that adding a quadratic in years of service leaves the other estimates basically unchanged. Holding all else constant, including the values of LS, PDVA, and age, workers are more likely to withdraw with more years of service up to 12 years of service, at which point longer tenures are associated with a reduction in the probability of accepting a LS. In general, the observed relationships between both demographic characteristics 
and work history and the probability of withdrawing funds conform to expectations. We next propose several reasons why workers might not be highly responsive to the relative size of the LS and PDVA.

\section{Potential Explanations for the Observed Distributional Decisions}

We postulate five hypotheses on why the relative size of the lump sum distribution (LS) and the present discounted value of the annuity (PDVA) might not affect the distributional choice in the manner initially expected: (1) the potential of subsidized health insurance in retirement if one selects an annuity, (2) the likelihood of returning to work and continuing to build years of service, (3) the option value of keeping the account open and earning a 4 percent return until the option is executed, (4) uncertainty regarding the future benefit and attitudes towards risk, and (5) inertia, inadequate financial literacy, and the lack of knowledge about the choices and their relative value. We now consider each of these relationships and their potential effect on the distributional choices of terminated vested workers. A discussion of how these factors might influence non-vested workers follows in Section 7.

The calculation of the PDVA makes a series of assumptions including a personal discount rate and a life expectancy from an actuarial life table. In addition, we are assuming that individuals are risk neutral. In this context, risk neutrality is a benign assumption, since technically a worker could withdraw funds and immediately roll them over into another tax qualified account. Because workers that request a LS have the option of rolling funds over into another tax qualified account without paying a penalty, or may withdraw funds but still save for retirement using other means, attitudes towards risk cannot explain choices in this context. An individual that has a higher personal discount rate or a lower life expectancy would value the annuity less than our calculation and would be more likely to take a LS. Similarly, separating 
workers that have a bequest motive would be more likely to withdraw funds. These and other personal characteristics have been proposed in the literature to explain the annuity puzzle ${ }^{25}$ that people do not purchase annuities, but do little to explain our results.

\subsection{Access to Subsidized Health Insurance in Retirement.}

The present value of the retirement annuity in the regression analysis was based solely on the cash benefit one could expect to receive in retirement. However, as described above, vested employees in the TSERS (teachers and state government workers) system who leave their

pension account open and ultimately receive a retirement benefit are also eligible to participate in the state health plan (SHP) once they begin receiving the pension. The state will pay 100 percent of the health insurance premium for these former employees. ${ }^{26}$ Persons who accepted the lump sum are not eligible for participation in the state health plan in the future.

Appendix A provides a calculation of the present discounted value of health insurance beginning when the retirement annuity starts and ending with death. Health insurance is a relatively valuable benefit, and according to our calculations described in Section 3, those who anticipate taking advantage of this benefit would see the PDVA plus the present value of the health insurance exceed the LS amount regardless of years of service and/or age at hire. To give a sense of the magnitude of the health insurance benefit relative to the annuity in the data, we estimate that the present discounted value of health insurance for our sample is between $\$ 37,225$

\footnotetext{
${ }^{25}$ Brown (2001) discusses the annuity puzzle in detail in a similar context for private sector workers. He surveys the empirical work on this issue and develops a concept of annuity equivalent wealth variable to partially explain decisions to annuitize wealth in defined contribution retirement plans.

${ }^{26}$ In 2011, the North Carolina General Assembly passed legislation that for the first time required a premium to be paid by active and retired workers for the Standard Plan offered by the state; however, workers and retirees still had access to the Basic Plan without having to pay a premium (Clark and Morrill, 2011).
} 
and $\$ 47,854$, depending on the individuals' age at separation and sex. ${ }^{27}$ We find that all but ten vested separating workers have smaller LS's when compared to the combined value of the PDVA and health insurance benefit. When considering the choices of workers covered by retiree health insurance, it is much less surprising that only 29 percent choose to withdraw funds within one year of separation.

Of course, this assessment of the relative value of the distributional options assumes that the departing worker believes that the benefit will still be provided by the time she retires and that she intends to claim the health insurance benefit. The cost and liabilities associated with state retiree health plans have been critically examined since new reporting standards were required by the Governmental Accounting Standards Board (Pew Center on the States, 2011; Clark and Morrill, 2010). The unfunded liabilities have been widely reported in the popular press, and many states (including North Carolina) have been modifying the terms of these plans. Thus, it would not be surprising if public employees doubted that the currently promised benefits will still be provided in 10 or 20 years. Reflecting this concern, terminated workers may further discount the value of future health insurance in retirement provided by the state. In addition, some workers may have access to health insurance through spousal coverage, so they might not value this benefit as much.

\footnotetext{
${ }^{27}$ To the extent that some vested workers will start their retirement annuity prior to age 65 , the value of retiree health insurance is underestimated, perhaps by a considerable amount. Individuals who are receiving a retirement annuity are covered by the state health plan regardless of age or whether the person is receiving a normal retirement benefit or one reduced due to age and service. For example, a worker who was hired at 25 and left state employment at age 45 could select to begin a reduced retirement benefit at age 50, she would also be eligible to participate in the state health plan at no premium. The subsidy for the health insurance does not vary with age at which the individual retires. As noted earlier, the value of the pension benefit is actuarially reduced to reflect earlier retirement ages; but as we see here, the present value of the health insurance would be much higher for those who accept benefits prior to age 65 .
} 


\subsection{Potential for Returning to Work and the Distributional Choice.}

If terminated workers anticipate that they may return to public employment in North Carolina, they may wish to keep their accounts open. Terminated workers who return to public employment will retain their service based on previous public employment provided they kept their accounts open and do not take a LS. Thus, an employee who temporarily leaves her job due to medical or family reasons with the intent of returning to public employment within a few years may find it convenient and cost-effective to leave her account open. Moreover workers who accept the LS can "purchase back" their prior years of service at a price specified by the plan.

To explore this question, we consider all workers who left the retirement systems in 2007 and 2008 and observe whether they had returned to public employment by the end of 2009 . Surprisingly, a greater proportion of those who returned to public employment had accepted a LS. Among those that returned to employment, 44 percent of the vested and 48 percent of the non-vested terminators had selected a LS. In contrast, only about one-third of both vested and non-vested employees who had not returned to public employment chose a LS. It should be emphasized that our time period for return to work is only one to two years, so the impact could be substantially different if we had data over a longer time period.

\subsection{Option Value of Maintaining a Pension Account.}

A terminated worker can request a LS at any time after leaving public employment up until she actually starts a retirement annuity. For vested individuals, the account balance continues to increase each year by a plan-specified interest rate of four percent. Thus, a well informed individual could view this as an investment option. She could request a LS and invest the money herself, or leave the money with the state plans and earn a guaranteed return of 4 
percent. Given the uncertainty in the financial markets during this period, a guaranteed return of 4 percent may have been an attractive investment. Data provided by the retirement system suggests that most LS's occur relatively close to the date of termination. ${ }^{28}$ A longer time series on when terminated workers requested a LS would provide better insight into this issue. ${ }^{29}$

\subsection{Confidence in the Retirement System.}

Over the past few years, the popular press has included many front page stories about the financial problems facing public pension plans, including the rising cost of providing these benefits and low funding ratios. North Carolina has one of the best funded public pension plans in the U.S. Analyzing 2009 pension data from the Comprehensive Annual Financial Reports of the states, the Pew Center on the States (2011) ranks North Carolina as the fourth best funded state retirement plan, with a funding ratio of 97 percent. ${ }^{30}$ Still, many states have been making major changes in their retirement plans. In most states changes will apply only to new employees. However, some states whose plans are facing substantial funding problems have been altering the benefits for current workers and reducing COLAs for current retirees. In this environment, terminated workers may question whether their pension plans will remain

\footnotetext{
${ }^{28}$ In 2010, 12,501 terminated workers accepted a LS. Of these 8,473 individuals received the distribution within one year of termination, another 1,234 had been gone for between one and two years, and another 1,677 requested a LS between two and five years after leaving the retirement systems. Thus, ninety-one percent of all LS's paid in 2010 were to individuals who left public employment within the last five years. ${ }^{29}$ An interesting thought experiment is to consider a hypothetical pension plan with all the characteristics of the North Carolina plan except that there is no annuity benefit. This simplifies the distributional choice to taking an immediate LS or leaving the account open and take the LS at some future date with the account balance increasing by 4 percent per year. If we could observe individuals covered by such a plan, it would be interesting to know the distribution of when workers accepted a LS. In essence, this becomes a portfolio choice with the pension serving as a guaranteed value fund with a 4 percent return. Depending on personal characteristics and the size of the pension account, we would probably observe some variation in the time since termination that the LS is requested.

${ }^{30}$ While most economists believe that the assumed rates of return in these reports are too high, the relative ranking of the North Carolina retirement system as one of the best funded retirement plans does not change when lower rates of return are employed (Novy-Marx and Rauh, 2011).
} 
unchanged for 10, 20 or 30 years. Doubts about the stability of the plans may have led some separated workers to be more likely to request a LS.

\subsection{Financial Literacy and Plan Knowledge.}

Considerable survey evidence indicates that workers have a low level of financial literacy and inadequate knowledge about their pension plans and how choices can affect the value of the retirement account (Lusardi and Mitchell, 2007; Clark, Morrill, and Allen, 2012). If workers who leave the North Carolina retirement system possess the same low levels of knowledge, it should not be surprising that they do not always select the option that has the greatest present value. While information about the size of the LS is easily available, separating workers may not be able to determine the value of the retirement annuity. Further, the retirement system sends all separated employees who request a LS a personalized form letter (shown in Appendix C), regardless of their vesting status or the relative size of their benefits. The letter contains a warning that if the refund is processed the individual will forfeit a future annuity benefit. A separating worker who is not confident in his/her choice may be swayed by the strong wording in this letter. We do not know how many individuals first applied but then ultimately chose not to withdraw funds after having received this letter.

Recent economic research has also shown that defaults matter in the selection of various pension options and inertia associated with the acceptance of defaults could also be affecting the distributional choices (e.g., Madrian and Shea, 2001). Brown, et al. (2008) describe an important role for framing. If workers accept defaults due to inertia or lack of understanding, or are not appropriately valuing benefits, then public employers could improve separating workers' welfare by providing timely and accessible financial education and information. 


\section{Distributional Choices of Non-Vested Workers}

Workers leaving public employment with fewer than five years of service are not vested according to the rules of both retirement plans (TSERS and LGERS), so they are not eligible for a retirement annuity based on service at the time of termination. Accordingly, the lump sum distribution (LS) available to them is the sum of their own pension contributions during their employment without any interest. Nevertheless, they are not required to immediately request a LS and the default is to maintain the account with the system. Given the choice of money now or the same amount of money at some future date, we would expect that all non-vested terminated workers would request immediate LS's. Yet, Table 2 shows that only about one-third of these former public employees requested a LS in the first year following termination. ${ }^{31}$

At first glance, this is quite puzzling. Unlike the vested workers, non-vested terminated employees cannot look forward to a retirement annuity, will not be eligible for state-provided retiree health insurance, and do not earn interest on the money left with the retirement system. But workers with short service may have paid very little attention to their pension accounts, and upon termination, may be unaware of the value of their accounts and the distributional options available to them. Inertia is often given as an explanation of certain types of behavior and could also be a factor in lack of immediate LS's. ${ }^{32}$

Still, there may be a fully rational reason for a separating employee to leave the monies in the system, even if not vested. Employees who leave public employment but who anticipate

\footnotetext{
${ }^{31}$ Using a longer time series, it would be interesting to discover whether these individuals ever return to public employment in North Carolina and ultimately become vested in the retirement plan, whether they ever request a LS, or whether these funds are permanently lost to the individual.

${ }^{32}$ Interestingly, inertia may be overcome by certain events. The state retirement system reports that requests for lump sum distributions from previously terminated workers often spike just before Christmas.
} 
returning to a government job may have an economic incentive to leave their pension accounts open, as returning civil servants who have not closed their pension accounts can count prior years of service in the determination of future retirement benefits. If this motive explains the distributional choices of non-vested employees, it would indicate rational decision making based on considerable knowledge of the pension plan. Family circumstances, such as the birth of a child or relocation, can also result in individuals quitting current employment and having temporary periods outside the labor force. The public sector is relatively large and all public employees are covered by the same system, offering considerable opportunities for future employment in either TSERS or LGERS. Nevertheless, the analysis of 2007-2008 terminations described in Section 6.2 does not support the hypothesis that expectations of returning to work is a cause of keeping one's account open since a larger proportion of those that returned to work had accepted a LS than those that had not yet returned to work.

To further examine the distributional choices of non-vested employees, we estimated a linear probability model with the dependent variable being an indicator for whether separating workers chose to withdraw their accounts and accept the LS's from the retirement plan within one year of terminating employment. The results of this regression are presented in Table 4 . We first consider how the value of the possible LS (the account balance) influences the choice of withdrawing funds. This relationship is shown to be quadratic, whereby the probability of withdrawing is increasing until the value of the account reaches approximately $\$ 15,000$, at which point the relationship becomes negative. Since none of these workers is eligible for an annuity, it is somewhat surprising that we observe this pattern, although it may be due to the possibility of returning to work in the future.

\section{[Table 4]}


In Table 4, Column (2), we observe that men were more likely to withdraw money. This could be due to less inertia or more knowledge among men. As was the case for vested employees, members of TSERS were significantly less likely to accept a LS than those in LGERS. Again, consistent with the patterns for vested workers, the youngest and oldest nonvested separating workers were least likely to withdraw funds, with the highest probability of withdrawing around age 42. As discussed earlier, this might be due to lack of knowledge or because of a higher likelihood to return to work among the youngest workers. In the final column of Table 4, we observe that controlling for years of service diminishes the coefficient on the account balance at separation somewhat. Here the omitted category is 2-2.99 years of service and we observe that among non-vested workers those with approximately 1-2.99 years of service are the most likely to withdraw. We observe across the columns of Table 4 that the importance of the size of the LS is only partially explained by observed work history and demographics, and the basic pattern suggests that those with the smallest and largest potential LS values are the least likely to withdraw within one year of separation.

\section{Cash Distributions or Rollovers}

Terminated employees who have requested a lump sum distribution (LS) have the option of directly receiving a check or having the funds sent from the retirement system directly to another tax qualified account, often an IRA. This form of distribution from a defined benefit plan is typically called a "rollover" of pension funds (see Figure 1). If the funds are rolled over, the monies are not counted as current income to the taxpayer, nor does the individual incur any tax penalty associated with the early withdrawal of funds from a retirement account. Thus, assets rolled over remain part of the individual's retirement wealth and can be invested through the new tax qualified plan. 
The impact of the rollover amount on retirement income will depend on the investment choices made and subsequent returns earned compared to the ultimate annuity that a vested worker could receive in the future. In our calculations for vested workers, the future annuity is discounted at a nominal rate of 5.8 percent. Thus, if the vested worker earned returns in excess of 5.8 percent, she might be able to purchase an annuity at retirement with a benefit that exceeded the benefit paid by the pension system. But the retail annuity market for an individual is relatively thin and includes fees, so the worker would likely have to earn a return greater than 5.8 percent in order to be able to purchase a comparable benefit in retirement. ${ }^{33}$

When a terminated worker requests that a check be sent directly to her, the distribution is subject to personal income tax in the year it is received. In addition, because all workers in our sample are under age 50, they will have to pay a 10 percent tax penalty for an early distribution. Once received, the payment can be spent on current consumption, used to pay off outstanding debts, or saved. Of course, if the monies are spent, potential income in retirement is reduced. Our data identify whether the LS was rolled over or paid as a cash distribution; however, we have no information on how the funds were subsequently used by terminated workers.

The possibility that the funds are spent, creating "leakage" from retirement saving, is a concern to many policy analysts. To investigate this pattern, we estimate a regression model exploring the determinants of how LS's are sent to terminated employees. The sample includes all individuals who left either of the two North Carolina retirement systems in 2007 and 2008, and who requested the LS. Overwhelmingly, workers who requested the LS opted for a cash

\footnotetext{
${ }^{33}$ In addition, the retirement annuity from the state plan is approximately a real annuity with benefits typically being increased each year by the legislature at a rate near the level of inflation. In contrast, the annuity that one could purchase in the market under these assumptions would be a nominal annuity.
} 
distribution; almost 90 percent of these individuals were sent a check directly from the retirement system. ${ }^{34}$ We estimate the decision separately for vested and non-vested workers. Non-vested workers seeking an annuity do not have the option of maintaining their account and eventually receiving a retirement annuity from the pension plans. We might therefore expect that among workers choosing to withdraw funds, the non-vested group would be more likely to rollover than the vested group, holding all else equal.

Table 5 reports the estimated coefficients from a linear probability model of the decision to cash out (versus rollover) benefits among those electing a LS. The estimates cover three alternative samples: all terminated employees who requested the LS, all vested workers receiving the LS, and all non-vested individuals that received the LS. Estimated coefficients are similar across the three data sets used in the analysis. For all groups, larger account balances significantly increased the probability of rolling the funds over into a tax qualified account. This may reflect the desire to avoid the higher tax and penalties associated with the cash distribution. Consistent with expectations given the alternative options for annuitizing, in Column (1) we observe that, holding all else constant, including the value of the LS, vested employees were 7.4 percentage points more likely to request a cash payment.

[Table 5]

\footnotetext{
${ }^{34}$ From October 2007 on, separating workers had the option of taking a partial rollover and requesting the balance in cash. These are recorded as rollovers in the data, and we cannot distinguish between full or partial rollovers. Therefore, our estimate of "leakage" may be understated, since some of those rolling over funds could also be taking out a portion in cash. We also expect that some separating employees do take cash and deposit it into a tax-qualified account themselves within the allowed 60 day period. We have no way of knowing how many workers exercise this option, either. Thus, the estimate of 90 percent leakage is slightly low because of partial rollovers and slightly high because of indirect rollovers not being observed.
} 
Across all three samples we see that among those requesting a LS, men are significantly more likely to cash out rather than directly rollover benefits. In Column (3) of Table 5 we see that non-vested participants in TSERS were 2.0 percentage points less likely to receive a cash distribution; however, there were no differences between vested members of TSERS and LGERS found in Column (2). The pattern of cashing out has an inverted u-shape by age for non-vested employees, while we do not find an effect for either age or years of service among vested employees, holding all else equal. For non-vested workers, an additional year of service increased the probability of accepting a check by 4.7 percentage points. Among separating workers requesting a LS, those terminating employment in 2008 were over two percentage points more likely to request cash relative to those separating in 2007.

The most important finding from this analysis is that almost 90 percent of terminated workers that requested a LS opted for a cash distribution. Given the economic conditions that prevailed during this period, one should not necessary conclude that this magnitude of leakage from retirement saving would prevails under normal situations. Combining these results with those presented earlier, that roughly one-third of all terminated workers request a LS, we estimate that approximately 28 percent of all terminated workers close their retirement accounts and receive a cash distribution within one year of separation.

\section{Key Findings and Conclusions}

Numerous studies have examined the distributional choice of pension participants. For the most part, these earlier papers focused on the private sector and used survey data that was based on recollection instead of real time decisions. Much of this literature tries to explain 'The Annuity Puzzle': why such a large proportion of vested terminated workers select lump sum distributions instead of an available annuity option. Reasons postulated include workers having 
very high discount rates and not appreciating the longevity insurance value of the annuity. In addition, terminating workers may have bequest motives or may be concerned about having liquid assets in the event of a health shock. Few have studied the public sector.

Our analysis shows that public employees face very different choices than do private sectors employees. Whereas private sector plans are constrained by law to offer lump sum distributions (LS's) that are greater than or equal to the present value of the future annuity, public sector pension plans base the LS on employee contributions and credited interest. Hence, the LS value is not directly linked to the value of the life annuity.

Using administrative records from North Carolina retirement plans, we provide a detailed picture of the distribution decisions of workers ages 18 to 49 that separated prior to retirement from public pension plans in North Carolina between 2007 and 2008. We show that, for younger workers and those with fewer years of service, the LS typically is larger in value than our approximation of the present value of the annuity (PDVA), yet only one-third elected the LS. This fraction does not differ considerably by vesting status or by eligibility for retiree health insurance. Almost 90 percent of separating workers who request a lump sum withdraw the funds as cash, rather than rolling over directly to another tax qualified retirement account. This could reflect a perceived need for cash for current consumption or paying off debts. It might also be the result of poor understanding of the tax consequences of this choice and the need to save these funds for retirement. Of course, workers could still deposit the cashed-out benefits into an IRA themselves. The high rate of cash-outs suggests a sizeable reduction in retirement wealth accumulation and suggests that there is a considerable amount of "leakage" from the retirement savings of public sector workers in North Carolina. 
In a related paper, Clark and Morrill (2012) find that among workers who separated from public employment in 2007-2008 and were eligible for an immediate reduced annuity (age 50 with at least 20 years of service), 90 percent opted to receive an immediate annuity. Of those who were eligible for an immediate unreduced annuity (30 years of service, age 62 with 25 years of service, or age 65 with 5 years of service), 99 percent selected some type of immediate annuity offered by the plan. Thus, for retiring public employees in North Carolina, almost all select an annuity option and reject the offer of a LS. On the basis of these findings and those in the current paper, it appears that public sector retirees in North Carolina are not part of annuity puzzle and instead overwhelming select annuities when they are offered.

One might expect that all non-vested terminations request a lump sum distribution since they are not entitled to a future retirement benefit and earn no interest on funds left with the system. Yet we observe that two thirds of those leaving the systems in 2007 and 2008 left their accounts open. Given the evidence on financial literacy and inertia in the general population, one might speculate that non-vested terminated workers are unaware of their ability to access these funds, do not understand that they have no claim on a future benefit, do not understand that the funds will not earn any interest, or simply do not take the time to request a LS. Economic and psychological studies indicate that workers often merely accept default options. In this case, the default is to leave the account open, thus we may think that workers leaving the system do not take the time to request a distribution of their pension account. To address this concern, the plan could change the default to be a LS for non-vested workers. Clark and Morrill (2012) find a similar result for non-vested workers over the age of 50 with only 36 percent of terminated workers aged 50 to 59 selecting a LS. While the proportion of those choosing a LS rises 
somewhat with advancing age (50 percent of those over age 65 chose the LS), it is hard to

explain why these older non-vested terminating workers would leave their funds with the system.

We postulate several factors that might explain why terminating workers for the most part do not appear to respond to the relative size of the PDVA and LS. While we discuss several reasons why the distribution choice is potentially more complicated than a simple present value calculation, we do not find empirical evidence pointing to one particular story. On the contrary, we find that there may be an important role for defaults and workers may not be well informed about the value of their benefits. Since defined benefit plans are much more prevalent in the public sector, these findings have significant economic and policy implications.

\section{REFERENCES}

Bassett, William, Michael Fleming, and Anthony Rodriguez. 1998. "How Workers Use 401(k) Plans: The Participation, Contribution, and Withdrawal Decisions," National Tax Journal, June, pp. 263-289.

Benartzi, Shlomo, Alessandro Previtero, and Richard Thaler. 2011. "Annuitization Puzzles," Journal of Economic Perspectives, pp. 143-164.

Brown, Jeffrey R. 2001. "Private Pensions, Mortality Risk, and the Decision to Annuitize," Journal of Public Economics, 82, 29-62.

Brown, Jeffrey R., Jeffrey R. Kling, Sendhil Mullainathan, and Marian V. Wrobel. 2008. "Why Don't People Insure Late-Life Consumption? A Framing Explanation of the UnderAnnuitization Puzzle," American Economic Review: Papers \& Proceedings, 98:2, 304-309.

Brown, Jeffrey R. and Scott Weisbenner. 2012. "Why do Individuals Choose Defined Contribution Plans? Evidence from Participants in a Large Public Plan," paper presented at "Retirement Benefits for State and Local Employees: Designing Pension Plans for the TwentyFirst Century” NBER conference, Jackson Wyoming.

Bryant, Victoria, Sarah Holden, and John Sabelhaus. 2011. "Qualified Retirement Plans: Analysis of Distribution and Rollover Activity," Pension Research Council Working Paper WP2011-01. 
Burman, Leonard, Norma Coe, and William Gale. 1999. "Lump Sum Distributions form Pension Plans: Recent Evidence Issues for Policy and Research," National Tax Journal. September, pp. 553-562.

Butler, Monika and Federica Teppa. 2007. "The Choice Between an Annuity and a Lump Sum: Results From Swiss Pension Funds," Journal of Public Economics, pp. 1944-66.

Chalmers, John and Jonathan Reuter. 2009. "How Do Retirees Value Life Annuities? Evidence from Public Employees.” NBER Working paper 15608.

Chang, Angela. 1996. "Tax Policy, Lump-Sum Pension Distributions, and Household Saving," National Tax Journal, June, pp. 235-52.

Clark, Robert, Lee Craig, and John Sabelhaus. 2011. State and Local Retirement Plans in the United States. Northhampton, MA: Edward Elgar Publishing.

Clark, Robert and Emma Hanson. 2011. "Distribution Options in State Pension Plans," NCSU Working Paper.

Clark, Robert and Melinda Morrill. 2010. Retiree Health Plans in the Public Sector: Is There a Funding Crisis? Northhampton, MA: Edward Elgar Publishing.

Clark, Robert and Melinda Morrill. 2011. "Containing Health Insurance Costs for Active and Retired Public Sector Employees: Lessons from the State of North Carolina," NCSU Working Paper.

Clark, Robert and Melinda Morrill. 2012. "Retiring Public Sector Employees Prefer Annuities to Lump Sum Distribution," North Carolina State University Working Paper.

Clark, Robert, Melinda Morrill, and Steven Allen. 2012. 'The Role of Financial Literacy in Determining Retirement Plans,' Economic Inquiry, 50 (October), pp. 851-866

Copeland, Craig. 2009. “Lump Sum Distributions at Job Change,” EBRI Notes, January, pp. 210 .

Engelhardt, Gary. 2002. "Pre-retirement Lump-sum Pension Distributions and Retirement Income Security: Evidence from the Health and Retirement Study," National Tax Journal, pp. 553-562.

Hurd, Michael and Constantijn Panis. 2006. "The choice to cash out pension rights at job change or retirement," Journal of Public Economics, pp. 2213-2227.

Lusardi, Annamaria, and Olivia S. Mitchell. 2007. "Baby Boomer Retirement Security: The Roles of Planning, Financial Literacy, and Housing Wealth," Journal of Monetary Economics, 54, pp. 205-224. 
Madrian, Brigitte and Dennis Shea. 2001. "The Power of Suggestion: Inertia in 401(k)

Participation and Savings Behavior," Quarterly Journal of Economics, pp. 1149-1187.

Mitchell, Olivia S., James M. Poterba, Mark J. Warshawsky, and Jeffrey R. Brown. 1999. "New Evidence on the Money's Worth of Individual Annuities," The American Economic Review, 89(5): 1299-1318.

Moore, James and Leslie Muller. 2002. “An Analysis of Lump-sum Pension Distribution Recipients," Monthly Labor Review, May, pp. 29-46.

Novy-Marx, Robert and Joshua Rauh. 2011. "Public Pension Liabilities: how Big Are They and What Are They Worth?” Journal of Finance, 66(4), 1207-1245.

Papke, Leslie. 2004. "Pension Plan Choice in the Public Sector: The Case of Michigan State Employees," National Tax Journal, LVII (2), 329-339.

Pew Center on the States. 2011. The Widening Gap: The Great Recession's Impact on State Pension and Retiree Health Cost, http://www.pewcenteronthestates.org/uploadedFiles/Pew_pensions_retiree_benefits.pdf

Poterba, James, Steven Venti, and David Wise. 1998. "Lump-Sum Distributions from Retirement Saving Plans: Receipt and Utilization." In David Wise (ed.), Inquiries into the Economics of Aging, Chicago: University of Chicago Press, pp. 85-105.

Poterba, James, Steven Venti, and David Wise. 2001 "Preretirement Cashouts and Foregone Retirement Saving: Implications for 401(k) Asset Accumulation," in David Wise (ed.) Themes in the Economics of Aging, Chicago: University of Chicago Press, pp. 23-58.

Purcell, Patrick. 2007. "Lump-Sum Distributions Under the Pension Protection Act," CRS Report For Congress, Order Code RS22765, December 3.

Purcell, Patrick. 2009. "Pension Issues: Lump-Sum Distributions and Retirement Income Security," CRS Report for Congress, January 7.

Sabelhaus, John and David Weiner. 1999. "Disposition of Lump-Sum Pension Distributions: Evidence from Tax Returns,” National Tax Journal, September, pp. 593-614.

U.S. Bureau of Labor Statistics. 2011. Employee Benefits Survey. http://bls.gov/ncs/ebs/benefits/2011/benefits_retirement.htm

Warner, John and Saul Pleeter. 2001. "The Personal Discount Rate: Evidence from Military Downsizing Programs," American Economic Review, pp. 33-53.

Yaari, Menahem E. 1965. "Uncertain Lifetime, Life Insurance, and the Theory of the Consumer,” Review of Economic Studies, 32(April): 137-150. 
Yakoboski, Paul. 1997. "Large Plan Lump Sums: Rollovers and Cashouts,” EBRI Issue Brief, vol. 188, Washington, DC: EBRI.

Yang, Tongxuan. 2005. "Understanding the Defined Benefit Versus Defined Contribution Choice," Pension Research Council WP 2005-4. 


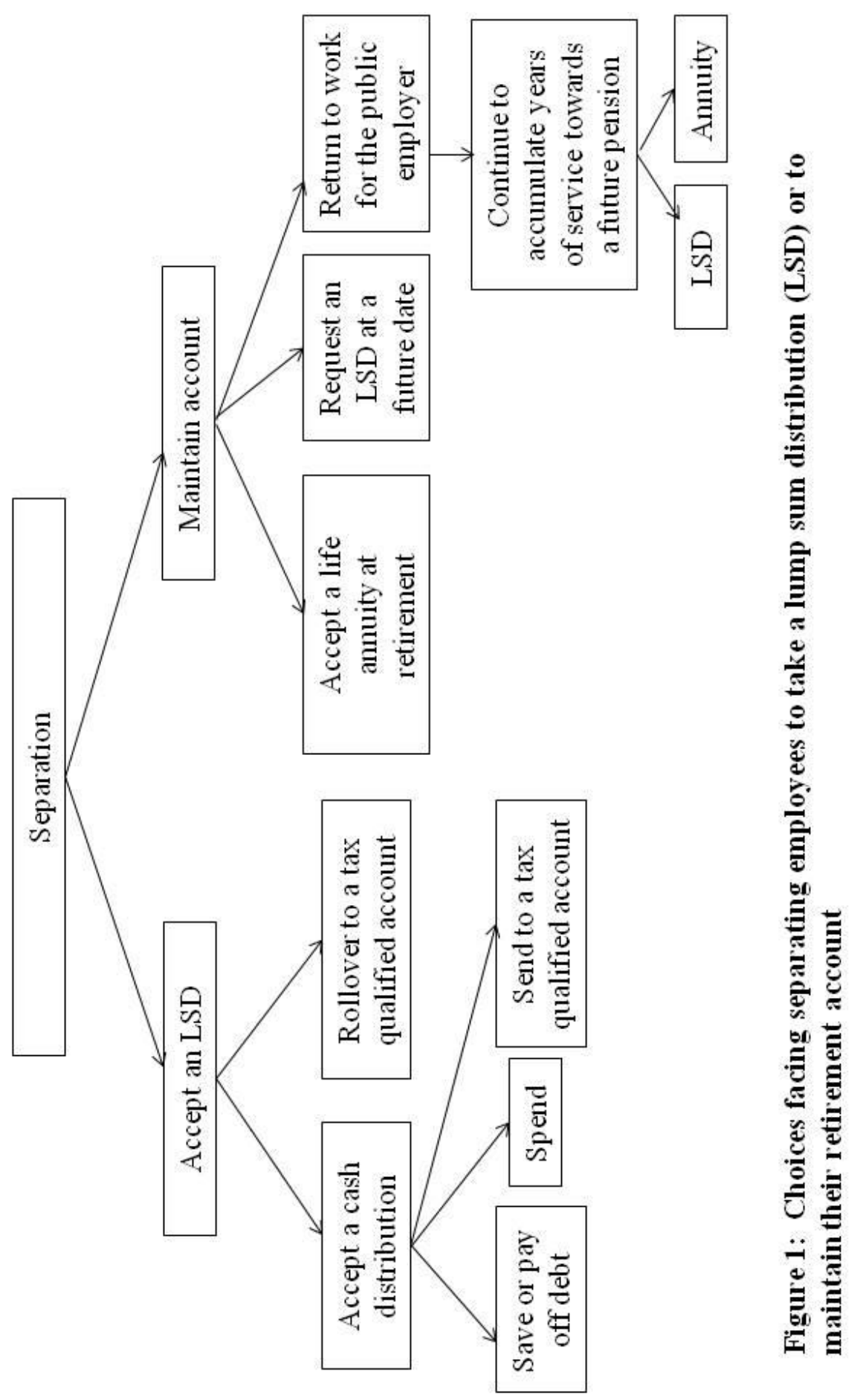




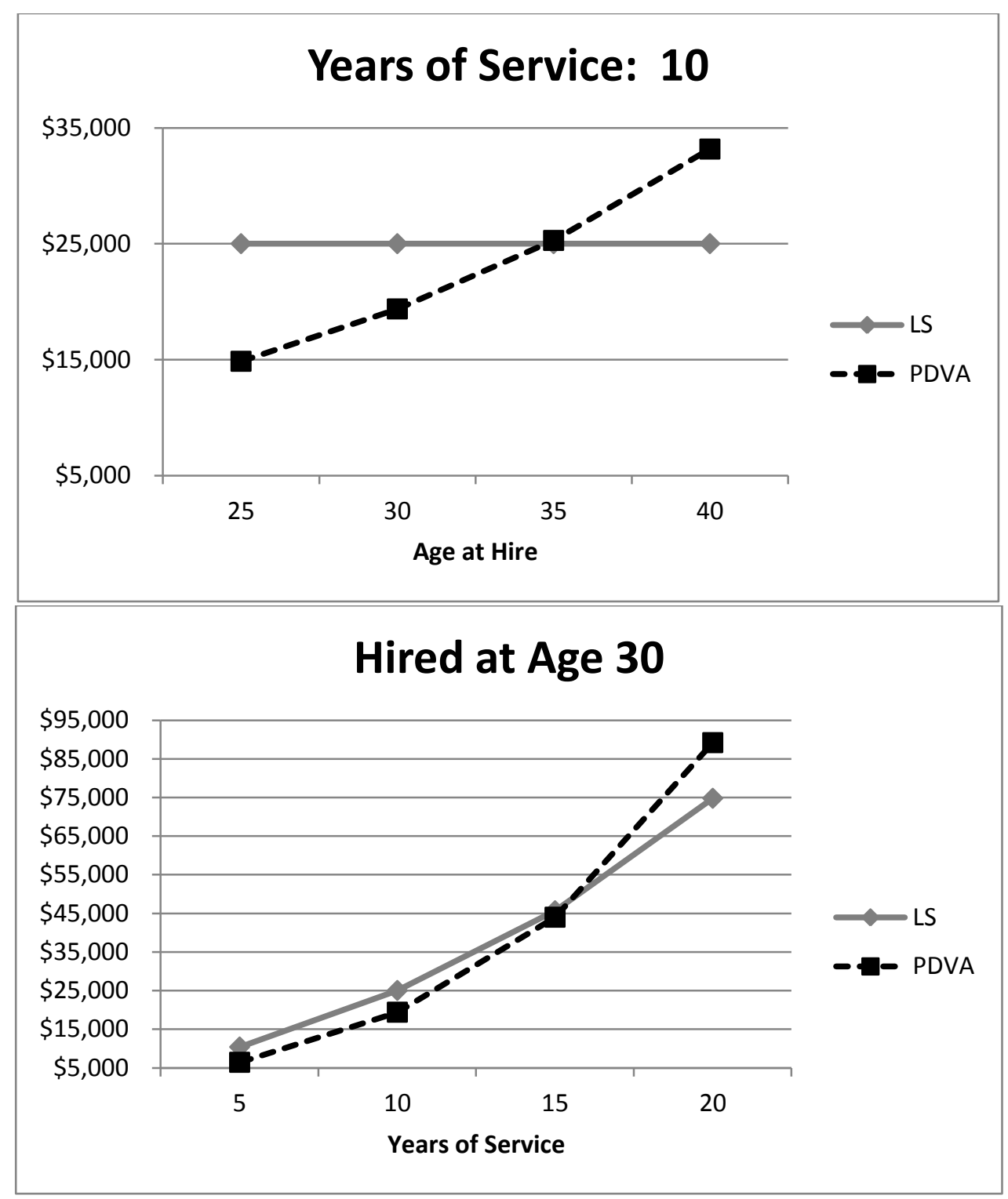

Notes: The values are calculated for a hypothetical separating employee earning a starting salary of $\$ 30,000$ per year with 3 percent wage growth. The top chart indicates the data points in dollar values calculated for a person with 10 years of service by the age of hire. The bottom chart indicates the data points in dollar values calculated for a person who was hired at age 30 by the number of years of service. The present discounted value of the annuity (PDVA) does not include the value of health insurance. Other simulation results (shown in Table 1) that vary the age of hire and years of service show a clear pattern that the lump sum distribution (LS) is greater relative to the PDVA for those hired at younger ages and with fewer years of service.

Figure 2: Simulation of relative values of lump sum distribution (LS) versus the present discounted value of the annuity (PDVA) 
Table 1: Value of Lump Sum (LS) and Present Discounted Value of Annuity (PDVA) for a Hypothetical Worker

\begin{tabular}{ccccc}
$\begin{array}{c}\text { Age at } \\
\text { Hire }\end{array}$ & $\begin{array}{c}\text { Age at } \\
\text { Separation }\end{array}$ & $\begin{array}{c}\text { Years of } \\
\text { Service }\end{array}$ & LS & PDVA \\
\hline 25 & 30 & 5 & $\$ 10,741$ & $\$ 4,916$ \\
25 & 35 & 10 & $\$ 25,521$ & $\$ 14,858$ \\
25 & 40 & 15 & $\$ 45,485$ & $\$ 33,694$ \\
25 & 45 & 20 & $\$ 72,074$ & $\$ 67,967$ \\
25 & 50 & 25 & $\$ 107,089$ & $\$ 129,212$ \\
\hline 30 & 35 & 5 & $\$ 10,741$ & $\$ 6,408$ \\
30 & 40 & 10 & $\$ 25,521$ & $\$ 19,377$ \\
30 & 45 & 15 & $\$ 45,485$ & $\$ 43,972$ \\
30 & 50 & 20 & $\$ 72,074$ & $\$ 89,167$ \\
\hline 35 & 40 & 5 & $\$ 10,741$ & $\$ 8,357$ \\
35 & 45 & 10 & $\$ 25,521$ & $\$ 25,287$ \\
35 & 50 & 15 & $\$ 45,485$ & $\$ 57,687$ \\
\hline 40 & 45 & 5 & $\$ 10,741$ & $\$ 10,906$ \\
40 & 50 & 10 & $\$ 25,521$ & $\$ 33,174$ \\
\hline 45 & 50 & 5 & $\$ 10,741$ & $\$ 14,308$ \\
\hline
\end{tabular}

Notes: Values are for a hypothetical worker with a starting salary of $\$ 30,000$ and wage growth of 3 percent. Calculations of the lump sum distribution value (LS) and present discounted value of the annuity (PDVA) are described in the text and in detail in Appendix A. The shaded boxes highlight the larger value between the LS and PDVA. 
Table 2: Percent taking a lump sum distribution (LS) by vesting status

\begin{tabular}{|c|c|c|c|c|c|}
\hline \multirow{3}{*}{ Full Sample } & & \multicolumn{2}{|c|}{ Vested (5+ Yrs) } & \multicolumn{2}{|c|}{ Not Vested $(<5$ Yrs $)$} \\
\hline & & $\mathrm{N}$ & $\% \mathrm{LS}$ & $\mathrm{N}$ & $\% \mathrm{LS}$ \\
\hline & & 11,368 & $32.36 \%$ & 35,545 & $35.29 \%$ \\
\hline \multirow{2}{*}{ SEPARATION YEAR } & Year: 2007 & 5,619 & $34.95 \%$ & 17,836 & $38.34 \%$ \\
\hline & Year: 2008 & 5,749 & $29.83 \%$ & 17,709 & $32.22 \%$ \\
\hline \multirow{3}{*}{ SEX } & Men & 3,948 & $34.75 \%$ & 11,822 & $35.31 \%$ \\
\hline & Women & 6,903 & $26.08 \%$ & 21,924 & $30.19 \%$ \\
\hline & Unreported Gender & 517 & $98.07 \%$ & 1,799 & $97.33 \%$ \\
\hline \multirow{5}{*}{$\begin{array}{l}\text { TOTAL YEARS OF } \\
\text { SERVICE } \\
\text { (REPORTED) }\end{array}$} & Yrs Service Less Than 1 & & & 11,839 & $28.46 \%$ \\
\hline & Yrs Service 1-3 & & & 16,606 & $37.84 \%$ \\
\hline & Yrs Service 4 & & & 2,753 & $41.30 \%$ \\
\hline & Yrs Service 5-19 & 11,039 & $32.60 \%$ & & \\
\hline & Yrs Service 20-39 & 280 & $12.14 \%$ & & \\
\hline \multirow{3}{*}{$\begin{array}{l}\text { AGE AT } \\
\text { SEPARATION } \\
\text { (CALCULATED) }\end{array}$} & Age $18-24$ & 17 & $29.41 \%$ & 5,183 & $29.89 \%$ \\
\hline & Age 25-34 & 3,256 & $30.62 \%$ & 15,297 & $33.95 \%$ \\
\hline & Age 35-49 & 7,055 & $33.37 \%$ & 13,257 & $38.63 \%$ \\
\hline \multirow{2}{*}{$\begin{array}{l}\text { RETIREMENT } \\
\text { SYSTEM }\end{array}$} & LGERS & 3,644 & $40.45 \%$ & 11,023 & $40.82 \%$ \\
\hline & TSERS & 7,724 & $28.55 \%$ & 24,522 & $32.80 \%$ \\
\hline \multirow{6}{*}{$\begin{array}{l}\text { JOB } \\
\text { CLASSIFICATION } \\
\text { (October 2007- } \\
\text { December } 2008 \text { only) }\end{array}$} & $\begin{array}{l}\text { Education Professionals } \\
\text { (excludes higher ed) (1) }\end{array}$ & 2,798 & $19.16 \%$ & 8,690 & $23.27 \%$ \\
\hline & Skilled Labor (2) & 772 & $47.28 \%$ & 2,982 & $36.82 \%$ \\
\hline & $\begin{array}{l}\text { Professional, Government, } \\
\text { Admin (3) } \\
\text { University, Extension, and }\end{array}$ & 2,076 & $35.69 \%$ & 6,148 & $39.75 \%$ \\
\hline & Community College (4) & 184 & $14.67 \%$ & 323 & $35.60 \%$ \\
\hline & Public Safety (5) & 1,148 & $45.21 \%$ & 3,486 & $43.49 \%$ \\
\hline & $\begin{array}{l}\text { Health and Social Service } \\
\text { Professionals }(6)\end{array}$ & 622 & $27.01 \%$ & 2,226 & $33.38 \%$ \\
\hline \multirow{3}{*}{$\begin{array}{l}\text { Regression Sample } \\
\text { (non-missing salary } \\
\text { and gender) }\end{array}$} & Regression Sample & 10,818 & $29.30 \%$ & & \\
\hline & LS > PDVA & 7,977 & $29.55 \%$ & & \\
\hline & $\mathrm{LS} \leq \mathrm{PDVA}$ & 2,841 & $28.62 \%$ & & \\
\hline
\end{tabular}

Notes: The sample includes all separating employees ages 18-49 who are not eligible to start an immediate retirement annuity. The sample size varies across worker and plan characteristics due to missing values for some workers. Note that for the regression sample of vested workers, 550 observations were dropped because the present discounted value of the annuity (PDVA) could not be determined from the data due to missing gender and/or salary. We report the number of workers and the percent taking a lump sum distribution (LS) versus maintaining their account. 
Table 3: Withdrawal Decisions of Vested Workers

\begin{tabular}{|c|c|c|c|c|c|c|}
\hline & $\begin{array}{l}\text { Mean/ } \\
\text { Percent }\end{array}$ & (1) & (2) & (3) & (4) & (5) \\
\hline Value of the LS (10K) & $\$ 2.02$ & $\begin{array}{c}-0.188 * * \\
(0.018)\end{array}$ & $\begin{array}{c}-0.209 * * \\
(0.018)\end{array}$ & $\begin{array}{c}-0.193 * * \\
(0.018)\end{array}$ & $\begin{array}{c}-0.217 * * \\
(0.019)\end{array}$ & $\begin{array}{r}-0.236^{* *} \\
(0.024)\end{array}$ \\
\hline Value of the LS $(10 \mathrm{~K})^{2}$ & & $0.013 * *$ & $0.014 * *$ & $0.012 * *$ & $0.013 * *$ & $0.017 * *$ \\
\hline & & $(0.002)$ & $(0.002)$ & $(0.002)$ & $(0.002)$ & $(0.003)$ \\
\hline PDVA $(10 K)$ & $\$ 1.75$ & $\begin{array}{l}0.093 * * \\
(0.013)\end{array}$ & $\begin{array}{l}0.100 * * \\
(0.013)\end{array}$ & $\begin{array}{l}0.108 * * \\
(0.013)\end{array}$ & $\begin{array}{c}0.136 * * \\
(0.015)\end{array}$ & $\begin{array}{l}0.162 * * \\
(0.016)\end{array}$ \\
\hline $\operatorname{PDVA}(10 \mathrm{~K})^{2}$ & & $\begin{array}{l}-0.005 * * \\
(0.001)\end{array}$ & $\begin{array}{c}-0.005 * * \\
(0.001)\end{array}$ & $\begin{array}{c}-0.005 * * \\
(0.001)\end{array}$ & $\begin{array}{l}-0.006 * * \\
(0.001)\end{array}$ & $\begin{array}{r}-0.007 * * \\
(0.001)\end{array}$ \\
\hline LS > PDVA & $73.7 \%$ & $\begin{array}{l}0.054 * * \\
(0.015)\end{array}$ & $\begin{array}{c}0.050 * * \\
(0.015)\end{array}$ & $\begin{array}{l}0.061 * * \\
(0.015)\end{array}$ & $\begin{array}{l}-0.017 \\
(0.018)\end{array}$ & $\begin{array}{l}-0.009 \\
(0.018)\end{array}$ \\
\hline Male & $36.4 \%$ & & $\begin{array}{l}0.101 * * \\
(0.009)\end{array}$ & $\begin{array}{c}0.104 * * \\
(0.009)\end{array}$ & $\begin{array}{c}0.115^{* *} \\
(0.009)\end{array}$ & $\begin{array}{l}0.119 * * \\
(0.009)\end{array}$ \\
\hline TSERS & $68.3 \%$ & & $\begin{array}{c}-0.104 * * \\
(0.009)\end{array}$ & $\begin{array}{c}-0.105^{* *} \\
(0.009)\end{array}$ & $\begin{array}{c}-0.099 * * \\
(0.009)\end{array}$ & $\begin{array}{r}-0.097 * * \\
(0.009)\end{array}$ \\
\hline $\begin{array}{l}\text { Final Average Salary } \\
(10 \mathrm{~K})\end{array}$ & $\$ 3.36$ & & & $\begin{array}{c}-0.027 * * \\
(0.008)\end{array}$ & $\begin{array}{c}-0.045^{* *} \\
(0.009)\end{array}$ & $\begin{array}{r}-0.053 * * \\
(0.012)\end{array}$ \\
\hline $\begin{array}{l}\text { Final Average Salary } \\
(10 \mathrm{~K})^{2}\end{array}$ & & & & $\begin{array}{c}0.001 \\
(0.001)\end{array}$ & $\begin{array}{l}0.002 * \\
(0.001)\end{array}$ & $\begin{array}{l}0.001 * \\
(0.001)\end{array}$ \\
\hline Age at Separation & 38.47 & & & & $\begin{array}{c}0.082 * * \\
(0.010)\end{array}$ & $\begin{array}{l}0.075 * * \\
(0.010)\end{array}$ \\
\hline Age at Separation ${ }^{2} / 100$ & & & & & $\begin{array}{c}-0.115^{* *} \\
(0.013)\end{array}$ & $\begin{array}{r}-0.107 * * \\
(0.013)\end{array}$ \\
\hline Years of Service & 9.01 & & & & & $\begin{array}{c}0.024 * * \\
(0.006)\end{array}$ \\
\hline Years of Service ${ }^{2}$ & & & & & & $\begin{array}{l}-0.001 * * \\
(0.0002)\end{array}$ \\
\hline Separated in 2008 & $52.9 \%$ & $\begin{array}{l}0.018 * \\
(0.009)\end{array}$ & $\begin{array}{c}0.025 * * \\
(0.009)\end{array}$ & $\begin{array}{c}0.026 * * \\
(0.009)\end{array}$ & $\begin{array}{c}0.027 * * \\
(0.009)\end{array}$ & $\begin{array}{c}0.027 * * \\
(0.009)\end{array}$ \\
\hline Constant & & $\begin{array}{c}0.418 * * \\
(0.017)\end{array}$ & $\begin{array}{c}0.477 * * \\
(0.018)\end{array}$ & $\begin{array}{c}0.511 * * \\
(0.021)\end{array}$ & $\begin{array}{c}-0.809 * * \\
(0.171)\end{array}$ & $\begin{array}{r}-0.742 * * \\
(0.171)\end{array}$ \\
\hline
\end{tabular}

Notes: The sample is all workers ages 18-49 that terminated employment in 2007 and 2008 and who were vested with valid entries for the above covariates, $N=10,818$. For more information on the sample for this table, see Table 2 and Appendix B. The dependent variable is the decision to withdraw the account balance and take a lump sum distribution (LS) within one year of separation versus maintaining the account (leaving it open with the possibility of electing for an annuity once eligible), approximately 29.3 percent of the sample requests a LS. The (LS > PDVA) is an indicator for whether the value of the LS is greater than the calculated present discounted value of the annuity (PDVA). Coefficients are estimated from a linear probability model with standard errors in parentheses. $*$ significant at $5 \%$; ** significant at $1 \%$. 
Table 4: Withdrawal Decisions of Non-Vested Workers

\begin{tabular}{|c|c|c|c|c|c|}
\hline & Mean/Percent & (1) & (2) & (3) & (4) \\
\hline \multirow[t]{2}{*}{ Value of the LS (1K) } & $\$ 3.15(\mathrm{~K})$ & $0.030 * *$ & $0.029 * *$ & $0.028 * *$ & $0.022 * *$ \\
\hline & & $(0.001)$ & $(0.001)$ & $(0.001)$ & $(0.002)$ \\
\hline \multirow[t]{2}{*}{ Value of the LS $(1 \mathrm{~K})^{2}$} & & $-0.001 * *$ & $-0.001 * *$ & $-0.001 * *$ & $-0.001 * *$ \\
\hline & & $(0.000)$ & $(0.000)$ & $(0.000)$ & $(0.000)$ \\
\hline \multirow[t]{2}{*}{ Male } & $33.3 \%$ & & $0.043 * *$ & $0.045^{* *}$ & $0.047 * *$ \\
\hline & & & $(0.005)$ & $(0.005)$ & $(0.005)$ \\
\hline \multirow[t]{2}{*}{ TSERS } & $69.0 \%$ & & $-0.062 * *$ & $-0.061 * *$ & $-0.064 * *$ \\
\hline & & & $(0.005)$ & $(0.005)$ & $(0.005)$ \\
\hline \multirow[t]{2}{*}{ Age at Separation } & 33.3 & & & $0.016^{* *}$ & $0.017 * *$ \\
\hline & & & & $(0.003)$ & $(0.003)$ \\
\hline \multirow[t]{2}{*}{ Age at Separation ${ }^{2}$} & & & & $-0.019 * *$ & $-0.019 * *$ \\
\hline & & & & $(0.004)$ & $(0.004)$ \\
\hline \multirow[t]{2}{*}{ 0-0.99 Years of Service } & $33.3 \%$ & & & & $-0.053 * *$ \\
\hline & & & & & $(0.010)$ \\
\hline \multirow[t]{2}{*}{ 1-1.99 Years of Service } & $28.2 \%$ & & & & 0.009 \\
\hline & & & & & $(0.008)$ \\
\hline \multirow[t]{2}{*}{ 3-3.99 Years of Service } & $12.2 \%$ & & & & $-0.019 *$ \\
\hline & & & & & $(0.009)$ \\
\hline \multirow[t]{2}{*}{ 4-4.99 Years of Service } & $7.8 \%$ & & & & $-0.025^{*}$ \\
\hline & & & & & $(0.012)$ \\
\hline \multirow[t]{2}{*}{ Separated in 2008} & $49.8 \%$ & $-0.067 * *$ & -0.003 & -0.003 & -0.002 \\
\hline & & $(0.005)$ & $(0.005)$ & $(0.005)$ & $(0.005)$ \\
\hline \multirow[t]{2}{*}{ Constant } & & $0.311^{* *}$ & $0.277^{* * *}$ & -0.049 & -0.023 \\
\hline & & $(0.005)$ & $(0.006)$ & $(0.050)$ & $(0.051)$ \\
\hline
\end{tabular}

Notes: The sample is all workers ages 18-49 that terminated employment in 2007 and 2008 and who were not vested (less than five years of membership plus non-contributory service) with valid entries for the above covariates, $N=35,545$. For more information on the sample for this table, see Table 2 and Appendix B. The dependent variable is the decision to withdraw the account balance and take a lump sum distribution (LS) within one year of separation; approximately 35.29 percent chose this option. The omitted category is 2-2.99 years of service. Also included in the specifications in Columns (2)-(4), but not reported, is a dummy variable for gender unknown (5.1\% of the sample). Coefficients are estimated from a linear probability model with standard errors in parentheses. $*$ significant at $5 \%$; $* *$ significant at $1 \%$. 
Table 5: The Decision to Cash Out versus Rollover Benefits among Vested and Non-Vested Workers Accepting a Lump Sum Distribution (LS)

\begin{tabular}{|c|c|c|c|c|c|c|}
\hline & $\begin{array}{r}\text { Full } \\
(\mathbf{8 8 . 7 \%}\end{array}$ & $\begin{array}{l}\text { ample } \\
\text { cash out) } \\
\text { l) }\end{array}$ & $\begin{array}{r}\mathrm{Vc} \\
(87.3 \%\end{array}$ & $\begin{array}{l}\text { sted } \\
\text { cash out) } \\
\text { 2) }\end{array}$ & $\begin{array}{r}\text { Non- } \\
\text { (89.1\% }\end{array}$ & $\begin{array}{l}\text { Vested } \\
\text { cash out) } \\
\text { 3) }\end{array}$ \\
\hline & Mean & Coeff. & Mean & Coeff. & Mean & Coeff. \\
\hline Value of the LS (10K) & 0.66 & $\begin{array}{c}-0.238^{* * *} \\
(0.013)\end{array}$ & 1.75 & $\begin{array}{c}-0.141^{* *} \\
(0.036)\end{array}$ & 0.35 & $\begin{array}{c}-0.487 * * \\
(0.029)\end{array}$ \\
\hline Value of the LS $(10 \mathrm{~K})^{2}$ & & $\begin{array}{c}0.020 * * \\
(0.002)\end{array}$ & & $\begin{array}{l}0.007^{*} \\
(0.003)\end{array}$ & & $\begin{array}{c}0.075^{* *} \\
(0.012)\end{array}$ \\
\hline Final Average Salary (10K) & & & 3.12 & $\begin{array}{l}-0.008 \\
(0.018)\end{array}$ & & \\
\hline Final Average Salary $(10 \mathrm{~K})^{2}$ & & & & $\begin{array}{c}0.002 \\
(0.001)\end{array}$ & & \\
\hline Vested & $22.7 \%$ & $\begin{array}{c}0.074 * * \\
(0.011)\end{array}$ & & & & \\
\hline Male & $34.2 \%$ & $\begin{array}{c}0.031 * * \\
(0.005)\end{array}$ & $43.3 \%$ & $\begin{array}{l}0.027^{*} \\
(0.012)\end{array}$ & $33.3 \%$ & $\begin{array}{c}0.033 * * \\
(0.006)\end{array}$ \\
\hline Unreported Gender & $13.9 \%$ & $\begin{array}{c}0.030 * * \\
(0.008)\end{array}$ & & & $14.0 \%$ & $\begin{array}{c}0.033^{* * *} \\
(0.009)\end{array}$ \\
\hline TSERS & $63.2 \%$ & $\begin{array}{c}-0.017^{* *} \\
(0.005)\end{array}$ & $60.0 \%$ & $\begin{array}{c}-0.007 \\
(0.012)\end{array}$ & $64.1 \%$ & $\begin{array}{c}-0.020 * * \\
(0.006)\end{array}$ \\
\hline Age at Separation & 34.9 & $\begin{array}{c}0.009^{* *} \\
(0.003)\end{array}$ & 38.4 & $\begin{array}{c}0.008 \\
(0.012)\end{array}$ & 34.0 & $\begin{array}{c}0.010^{* * *} \\
(0.003)\end{array}$ \\
\hline Age at Separation ${ }^{2} / 100$ & & $\begin{array}{l}-0.010^{*} \\
(0.004)\end{array}$ & & $\begin{array}{l}-0.009 \\
(0.015)\end{array}$ & & $\begin{array}{l}-0.012^{*} \\
(0.005)\end{array}$ \\
\hline Years of Service & 3.42 & $\begin{array}{c}0.024 * * \\
(0.004)\end{array}$ & 8.48 & $\begin{array}{c}0.014 \\
(0.011)\end{array}$ & 1.95 & $\begin{array}{c}0.047^{* *} \\
(0.010)\end{array}$ \\
\hline Years of Service ${ }^{2}$ & & $\begin{array}{l}-0.0004 \\
(0.0002)\end{array}$ & & $\begin{array}{c}0.0001 \\
(0.0004)\end{array}$ & & $\begin{array}{c}0.002 \\
(0.002)\end{array}$ \\
\hline Separated in 2008 & $45.7 \%$ & $\begin{array}{c}0.024 * * \\
(0.005)\end{array}$ & $54.0 \%$ & $\begin{array}{l}0.029^{*} \\
(0.012)\end{array}$ & $45.5 \%$ & $\begin{array}{c}0.026^{* * *} \\
(0.006)\end{array}$ \\
\hline Constant & & $\begin{array}{c}0.744 * * \\
(0.055)\end{array}$ & & $\begin{array}{c}0.783^{* *} \\
(0.221)\end{array}$ & & $\begin{array}{c}0.734^{* * *} \\
(0.060)\end{array}$ \\
\hline Observations & & 213 & & 167 & & 537 \\
\hline
\end{tabular}

Notes: The samples include only those separating workers who take a lump sum distribution (LS). For more information on the sample for this table, see Table 2 and Appendix B. Note that in Column (2) only workers whose final average salary could be calculated are included in the sample, as in Table 3 . The dependent variable is the decision to cash out the account balance (active termination refund or active termination refund federal tax) instead of directly rolling over into an IRA within one year of separation. Coefficients are estimated from a linear probability model with standard errors in parentheses.

$*$ significant at $5 \%$;* significant at $1 \%$. 


\section{APPENDIX A: Calculations of the Estimated Value of the Distribution Options}

\section{A.1. Calculation of the Lump Sum Distribution (LS) Value}

The value of the LS at the time of separation, $L S_{T}$, is the sum of the contributions in each period (six percent of annual salary) compounded at a four percent annual interest rate $(r)$. In the equation below, $T$ is equivalent to the years of service at separation. $S A L_{t}$ refers to the annual salary earned by the employee in time period $t$. If the worker began her career in year 0 and separated in year $T$, then we can write

$$
\text { (A.1) } L S_{t}=\sum_{t=0}^{T-1}\left[(0.06) *\left(S A L_{t}\right) *(1+r)^{T-t}\right]
$$

For simplicity, we assume that salary rises at a constant rate, g, per year. Then we can write the salary at time $t$ as a function of the initial hiring salary, $S A L_{0}$,

$$
\text { (A.2) } S A L_{t}=S A L_{0}(1+g)^{t}
$$

Combining equations (A.1) and (A.2) and solving the finite geometric series summation gives the following formula for calculating a worker's LS at separation time $T$ :

$$
\text { (A.3) } L S_{T}=0.06 * S A L_{0} *(1+r)\left[(1+r)^{T}-(1+g)^{T}\right] /(r-g) \text {. }
$$

The value of the LS increases with salary level, salary growth, and years of service, but it is independent of sex or age at hire.

\section{A2. Calculation of the Value of the Annuity Benefit}

The initial annual benefit, $B$, expected during each year of retirement, $R$, is calculated using the following formula:

$$
\text { (A.4) } B_{R}(\boldsymbol{T})=\boldsymbol{M} * \boldsymbol{T} * \boldsymbol{F} \boldsymbol{A} \boldsymbol{S}_{T},
$$

where $R$ indexes the age of retirement, $T$ is the number of years of service at separation, and FAS is the final average salary at separation. The pension multiplier, $M$, is 0.0182 for workers in 
TSERS and 0.0185 for workers in LGERS. We do not have access to a full earnings history for every separating worker, so we approximate the final average salary used to calculate the annual benefit. In our calculation, we average the last four full calendar years of earnings, while the actual benefit formula uses the average of the highest four consecutive years of earnings (this simplification should have only a minimal impact on the calculation of the FAS).

We calculate the present discounted value of the annuity by multiplying this annual benefit by an annuitization factor and a discounting factor. The annuitization factor, $A F_{R}$, is specific to the age of retirement, $R$. The discounting factor, $D(h, T)$, is a function of age at hire, $h$, and years of service, $T$. We write the present discounted value of the annuity (PDVA) for a worker that separates with $T$ years of service, assuming that benefits are claimed at age $R$, as:

\section{(A.5) $\quad P D V A_{T}=B_{R}(T) * A F_{R} * D(h, T)$.}

Next, the Annuity Factor, $A F$, is used to determine the value of retirement benefits from age $R$ until age at death, $T D$. The future annuity stream is adjusted to reflect cost of living increases, inflation, personal discount rates, and age-specific mortality rates according to the following function:

$$
\text { (A.6) } \quad A F_{R}=\sum_{s=R}^{T D} \frac{(1+\alpha)^{s-R} \text { Survival }_{s}^{R}}{\left(1+r_{N}\right)^{s-R}}
$$

In the past, retirees have been awarded cost of living increases (COLAs) each year. Over the past decade, the average annual COLA paid to retirees was 1.8 percent each year, ${ }^{35}$ so in

\footnotetext{
${ }^{35}$ Each year the legislature considers whether to award benefit increases to current retirees. Current law states that benefits can be raised only when the increase does not result in a higher employer contribution. Historically, benefit increases have been awarded almost every year. Between 2000 and 2009, the average annual increase in benefits was 1.8 percent. Given the actual and projected asset losses in 2008, future benefit increases may be less likely and lower for workers separating in the future.
} 
equation (A.6) we set $\alpha$ equal to $0.018 .^{36}$ The annual benefits are then discounted by the nominal interest rate, our proxy for the individuals' personal discount rate. The nominal interest rate, $r_{N}$, is assumed to be equal 5.8 percent, which is the real interest rate, 3.0 percent, plus the assumed inflation rate, 2.8 percent. Finally, Survival $\boldsymbol{R}_{\boldsymbol{S}}$ is the age-specific probability of surviving from age $R$ to age $s$ based on the 2000 life table that was used by the retirement system in its actuarial reports in 2007 and $2008 .^{37}$

When deciding whether to accept a LS at separation, the worker is interested in the PDVA at the time of job termination. Thus, the present value of the pension annuity at age $R$ must be discounted back to the age at separation. Since final salary is fixed when the individual leaves public employment, the benefit at age $R$ is determined in nominal dollars. Therefore, the present value at age $R$ is discounted by the nominal interest rate of 5.8 percent.

$$
\text { (A.7) } D(h, T)=\frac{\text { Survival } T_{R}^{T+h}}{\left(1+r_{N}\right)^{R-T-h}}
$$

Recall $h$ is the age at hire and $T$ is the years of service, so $T+h$ is the age at separation, while $R$ is the age of retirement assumed to be age 65 so that $(R-T-h)$ yields the number of years until retirement benefits commence. The term Survival indicates the probability of an individual

\footnotetext{
${ }^{36}$ To determine the real value of future benefits back to age 65, one can adopt the inflation assumption used by the Chief Actuary of the U.S. Social Security System of 2.8 percent per year. Thus benefits were increased at approximately 64 percent of the annual rate of inflation.

${ }^{37}$ The analysis does not include any post-retirement death benefits because alternative forms of annuity options available to retirees are calculated to be actuarially equivalent. Thus, the present value of the annuity chosen by a retiree includes any continuation of benefits after the worker's death. In general, the retirement systems do not provide any pre-retirement death benefits; this is in contrast to private sector plans that are required to offer certain pre-retirement death benefits.
} 
living until time period $R$ given they have survived until time period $T+h$. As above, we set $r_{N}$ to be 5.8 percent. $^{38}$

\section{A3. The Value of Health Insurance in Retirement}

In order to calculate the present value of access to the health plan, we start with the claims by age used in the 12/31/2009 valuation as reported in the actuarial statements on Other Post-Employment Benefits (OPEB). The current actuarial analysis of the retiree health plan assumes that the medical care cost rate to the system will increase by 5.0 percent per year after 2015. ${ }^{39}$ We increase claims by age by 5.0 percent per year from the time of separation until death. Next, we calculate the present value of coverage in the state health plan at age 65 by discounting the annual value of the health insurance from age 65 to death by the nominal interest rate of 5.8 percent. Since the implied value of health coverage does not vary with salary, this value will be the same for all employees at age 65 . The present value at age 65 is discounted back to age of termination by the nominal interest rate of 5.8 percent. The value of health insurance is also not related to years of service and so is completely determined by the worker's sex and age at separation.

\section{APPENDIX B: Data Construction}

The raw data provided by the retirement systems includes all individuals that separated employment in 2007 or 2008, which was calculated by looking at the date of the last contribution

\footnotetext{
${ }^{38}$ Note that some law enforcement officers are eligible to retire at earlier ages if their primary duties fall into certain categories. We will systematically underestimate the PDVA for those workers, but are not able to identify which workers are eligible. Where we do observe job classifications, approximately 10 percent have a position code that could make them eligible for the special benefit.

${ }^{39}$ While medical costs may increase at a rate greater than 5.0 percent per year, the authors assume, based on recent experience, that cost increases greater than 5.0 percent will be shifted to the employee in the form of higher deductibles and co-payments. Thus, the value to the employee should be expected to increase by 5.0 percent per year.
} 
to the retirement accounts and includes 85,351 observations. Appendix Table B.1 reports the sample selection criteria used to create the data used in the main analysis.

[Appendix Table B.1]

\section{MULTIPLE SPELLS}

We can observe multiple spells in the data, but do not have access to all past (or future, obviously) spells. For simplicity and consistency, we delete observations with multiple spells during our two year period. This removes 2,604 observations.

\section{RETIREMENTS}

Following the advice of the state retirement system's office, we define direct retirements as those who claim an annuity within one year of separation. Because our project is concerned with disposition choice for those separating prior to retirement, we have chosen to remove those that retire within one year of separation from our sample. This eliminates 728 observations.

\section{TOTAL YEARS OF SERVICE}

An individual's total years of service are not necessarily equal to his tenure at his employer. While one could calculate the years of service as the separation date minus the start date, this will differ from the total reported years of service if an individual has either noncontributory or purchased service. We therefore rely on the reported years of service.

There are three types of service reported in the data. First, membership service is the total years an individual worked and contributed to the retirement system. Second, noncontributory service includes qualified military service, disability (including maternity leave), or converted sick-leave. Non-contributory service does not count towards service in the final annuity calculation. Non-contributory service is "creditable" and does count towards vesting and eligibility for benefits. Third, purchased service reflects years of service an individual pays for 
from an eligible period of service. Examples include withdrawn service (with interest), out-ofstate service, educational leave, temporary or part-time local and state service, worker's compensation leave, or local or federal government service. Purchased service is creditable and qualifies the individual for benefits except vesting.

We define years of service three ways for the analysis:

(1) To be vested, membership and non-contributory service must equal five years.

(2) The variable "years of service at separation" used in the tables is meant to reflect eligibility for benefits, so is equal to the sum of all three types of service, membership, non-contributory, and purchased.

(3) To calculate the value of the annuity, we use the sum of membership and purchased service.

To maintain data quality, we restrict the sample to those individuals whose calculated years of service (date of termination minus date of hire) and membership service are at least 0.08 years (approximately one month) each. This eliminates 677 observations from the sample, but allows us to remove individuals that did not have any substantive claim on a retirement benefit.

\section{ACCOUNT BALANCE INFORMATION (Value of the LS)}

For active accounts: The current account balance reported in the data includes interest only if vested. According to the retirement system, missing values in this variable are likely caused by an employer erroneously reporting someone as meeting the requirements to participate in the retirement system, but really the person is a contractor or part-time employee. The employer then corrects that entry, taking back the contributions and leaving no money in the account. The account is still listed as active because the contributions were reversed, rather than withdrawn. These observations (99) have been dropped. For active accounts, the interest rate 
used is $4 \%$ and the account balance must be discounted at $4 \%$ to get the account balance at termination.

For closed/withdrawn accounts: The actual dollar amount refunded is reported in the data. If not vested, the refund amount is just the individuals' contribution without interest. The account balance at separation is therefore equal to the refund amount for those not vested. For

those who were vested, the account balance at separation is equal to the refund amount adjusted/discounted by the interest rate. To calculate the account balance at separation for vested individuals who withdrew their account a year later, the account balance is discounted back using a standard $4 \%$ interest rate.

\section{FINAL A VERAGE SALARY}

Last year's salary is available on the data set, but appears to be measured with considerable error. We use records of salaries paid from 2003 to 2007 to impute the average salary over the last full four calendar years of work. The annuity formula uses the highest four consecutive years of salary, so our measure will be weakly smaller than the true annuity value. We do not observe the salary for 33 observations, so must drop these from the analyses that use the PDVA calculations. 


\section{Appendix Table B.1: Sample Construction}

\begin{tabular}{|c|c|}
\hline \multicolumn{2}{|l|}{$\begin{array}{l}\text { All Separations Reported in } 2007 \text { and } 2008 \\
\qquad \mathrm{~N}=85,351\end{array}$} \\
\hline Restriction & $\begin{array}{l}\text { Number } \\
\text { Dropped }\end{array}$ \\
\hline Multiple observations in the sample period & 2,604 \\
\hline Date of birth year is 1900 or 1901 & 716 \\
\hline Age when hired less than 16 & 43 \\
\hline Age $70+$ at date of hire & 283 \\
\hline Age $80+$ at date of separation & 17 \\
\hline Age $<18$ at date of separation & 5 \\
\hline *Sample selection: Age at separation is $\mathbf{5 0 +}$ & 31,489 \\
\hline Time until retirement less than -90 days & 1 \\
\hline *Sample selection: Retired within 1 year of separation & 728 \\
\hline Time until withdrawal less than -90 days & 110 \\
\hline Retirement system is not TSERS or LGERS & 4 \\
\hline Missing years of service (total reported) & 1,613 \\
\hline Zero years of service (total reported) & 49 \\
\hline Total years of service (total reported) $>40$ & 0 \\
\hline Membership years of service $<0.08$ years (approximately 1 month) & 7 \\
\hline Calculated years of service (separation date-hire date) $<0.08$ years & 670 \\
\hline Account balance is missing (no non-zero account balance) & 99 \\
\hline \multicolumn{2}{|l|}{ Full Sample: 46,913 workers, 11,368 vested and 35,545 non-vested } \\
\hline \multicolumn{2}{|l|}{ For 11,368 vested, to calculate PDVA two additional restrictions: } \\
\hline Missing gender & 517 \\
\hline Missing (calculated) salary & 33 \\
\hline Vested Sample for PDVA calculations: $N=\mathbf{1 0 , 8 1 8}$ & \\
\hline
\end{tabular}

Notes: All restrictions are for data quality concerns, except for the sample selection as indicated by a $*$ preceding the description. The full sample is used for Tables 2 , 4 , and 5 , while Table 3 requires the sample where the present discounted value of the annuity (PDVA) can be calculated. 


\section{Appendix C: Retirement System Communications}

Regardless of the number of years of service, any separating employee requesting a lump sum distribution receives a personalized copy of the following letter which includes the individual's years of retirement service credit. We do not have information on how many individuals first applied but then ultimately chose not to withdraw funds or on the effectiveness of this intervention in particular. The data we have only reflect the final choice that separating workers made.

\section{Form 5 Letter:}

We have received your Withdrawing Your Retirement Service Credit and Contributions (Form 5) for the Teachers' and State Employees' Retirement System on $02 / 15 / 2010$ and have begun to process your request.

According to state law, we cannot issue a refund within sixty (60) days of the last day you were employed by a contributing employer.

Although we are proceeding with this refund, we find that you have 11.58330 years of retirement service credit. If you have 5.0000 or more years of retirement service credit, you may have a vested right to apply for monthly retirement benefits as soon as your age qualifies you. You may apply for a full retirement at age 65 (or at age 55 if a Law Enforcement Officer). You may apply for a reduced retirement at age 60 (or at age 50 if a Law Enforcement Officer with 15 years of membership service). You may also be entitled to further benefits in connection with your retirement, but these will be forfeit if you proceed with a refund. Please notify us in writing if, considering these benefits, you wish to cancel your application for a refund.

If you accept further employment covered by the Teachers' and State Employees' Retirement System before you receive your refund check, you should notify us immediately. We are not permitted to issue a refund to a person who has returned to service.

If we may be of further assistance, please contact us at the address or telephone number listed below.

Sincerely, 